\title{
Finance and Economic Development: Policy Choices for Developing Countries
}

\author{
Aslı Demirgüç-Kunt *
}

\begin{abstract}
The empirical literature on finance and development suggests that countries with better developed financial systems experience faster economic growth. Financial development - as captured by size, depth, efficiency and reach of financial systemsvaries sharply around the world, with large differences among countries at similar levels of income. This paper argues that governments play an important role in building effective financial systems and discusses different policy options to make finance work for development.
\end{abstract}

World Bank Policy Research Working Paper 3955, June 2006

The Policy Research Working Paper Series disseminates the findings of work in progress to encourage the exchange of ideas about development issues. An objective of the series is to get the findings out quickly, even if the presentations are less than fully polished. The papers carry the names of the authors and should be cited accordingly. The findings, interpretations, and conclusions expressed in this paper are entirely those of the authors. They do not necessarily represent the view of the World Bank, its Executive Directors, or the countries they represent. Policy Research Working Papers are available online at http://econ.worldbank.org.

* Senior Research Manager in Finance, Development Research Department, World Bank. The paper was written for publication in Bourguignon and Monga (2006) "Macroeconomic Issues in Low-Income Countries." The author is grateful to Meghana Ayyagari, Thorsten Beck, Bob Cull, Patrick Honohan, Vojislav Maksimovic and Sole Martinez for helpful comments and Edward Al-Hussainy for excellent research assistance. 
What is the role of the financial sector in economic development? Economists hold very different views. On the one hand, prominent researchers believe that the operation of the financial sector merely responds to economic development, adjusting to changing demands from the real sector, and is therefore overemphasized (Robinson, 1952; Lucas, 1988). On the other hand, equally prominent researchers believe that financial systems play a crucial role in alleviating market frictions and hence influencing savings rates, investment decisions, technological innovation and therefore long-run growth rates. (Schumpeter, 1912; Gurley and Shaw, 1955; Goldsmith, 1969; McKinnon, 1973; Miller 1998). ${ }^{1}$

Financial markets and institutions arise to mitigate the effects of information and transaction costs that prevent direct pooling and investment of society's savings. ${ }^{2}$ While some theoretical models stress the importance of different institutional forms financial systems can take, more important are the underlying functions that they perform (Levine, 1997 and 2000; Merton and Bodie, 2004). Financial systems help mobilize and pool savings, provide payments services that facilitate the exchange of goods and services, produce and process information about investors and investment projects to enable efficient allocation of funds, monitor investments and exert corporate governance after these funds are allocated, and help diversify, transform and manage risk.

While still far from being conclusive, the bulk of the empirical literature on finance and development suggests that well-developed financial systems play an

\footnotetext{
${ }^{1}$ Two famous quotes by Robinson and Schumpeter illustrate these different views. Joan Robinson (1952) argued "Where enterprise leads finance follows," whereas Joseph Schumpeter observed "The banker, therefore, is not so much primarily a middleman...He authorizes people in the name of society ...(to innovate)."

${ }^{2}$ See for example, Gurley and Shaw (1955), Diamond (1984), Boyd and Prescott (1986), Greenwood and Jovanovic (1990), Galor and Zeira (1993), Aghion et al. (2004) among others.
} 
independent and causal role in promoting long-run economic growth. More recent evidence also points to the role of the sector in facilitating disproportionately rapid growth in the incomes of the poor, suggesting that financial development helps the poor catch up with the rest of the economy as it grows. These research findings have been instrumental in persuading developing countries to sharpen their policy focus on the financial sector. If finance is important for development, why do some countries have growth-promoting financial systems while others do not? How do we define financial development? And what can governments do to develop their financial systems?

This chapter addresses these questions. The next section provides a brief review of the extensive empirical literature on finance and economic development and summarizes the main findings. Section II illustrates the differences in financial systems around the world and discusses the role of legal, cultural, political and geographical factors in influencing financial development. Section III discusses the governments' role in building effective financial systems. Section IV provides areas of particular emphasis for lower-income countries. Section V concludes.

\section{Finance and Economic Development: Evidence}

By now there is an ever-expanding body of evidence that suggests countries with better developed financial systems - mostly captured by depth and efficiency measuresexperience faster economic growth. ${ }^{3}$ Cross-country studies show that better developed banks and markets are associated with faster growth and that this relationship is robust to controlling for reverse causality or potential omitted variables (King and Levine, 1993; Levine and Zervos, 1998). These findings are also confirmed by panel and time-series

\footnotetext{
${ }^{3}$ See Levine (1997 and 2005) for a comprehensive review of this literature.
} 
estimation techniques (Levine, Loazya and Beck, 2000; Christopoulos and Tsionas, 2004; Rousseau and Sylla, 1999). Research also indicates that financial sector development helps economic growth through more efficient resource allocation and productivity growth rather than through the scale of investment or savings mobilization (Beck, Levine and Loayza, 2000). Furthermore, cross-country time-series studies also show that financial liberalization boosts economic growth by improving allocation of resources and the investment rate (Bekaert, Harvey and Lundblad, 2001 and 2005).

To further understand the relationship between financial development and economic growth, researchers have also employed both firm-level and industry-level data across a broad cross-section of countries. These studies better address causality issues and seek to discover the mechanisms through which finance influences economic growth.

Demirguc-Kunt and Maksimovic (1998) use firm level data and a financial planning model to show that more developed financial systems - as proxied by larger banking systems and more liquid stock markets- allow firms to grow faster than rates they can finance internally. Consistent with Demirguc-Kunt and Maksimovic (1998), Love (2003) also uses firm level data and shows that the sensitivity of investment to internal funds is greater in countries in less developed financial systems. Beck, Demirguc-Kunt and Maksimovic (2005) use firm level survey data for a broad set of countries and show that financial development eases the obstacles that firms face to growing faster, and that this effect is stronger particularly for smaller firms. Recent evidence also suggests that access to finance is associated with faster rates of innovation and firm dynamism consistent with the cross-country finding that finance promotes 
growth through productivity increases (Ayyagari, Demirguc-Kunt and Maksimovic, 2006).

Rajan and Zingales (1998) use industry level data across countries and show that industries that are naturally heavy users of external finance - as measured by the financeintensity of U.S. industries ${ }^{4}$ - benefit disproportionately more from greater financial development compared to other industries. Beck, Demirguc-Kunt, Laeven and Levine (2006) again using industry data, highlight a distributional effect: They find that industries that are naturally composed of small firms grow faster in financially developed economies, a result that provides additional evidence that financial development disproportionately promotes the growth of smaller firms. Also using industry-level data, Wurgler (2000) shows that countries with higher levels of financial development increase investment more in growing industries and decrease investment more in declining industries, compared to countries with underdeveloped financial systems.

There are also numerous individual country case studies that provide consistent evidence. For example, Jayaratne and Strahan (1996) compare states within the U.S. and show that bank branch reform boosted bank-lending quality and accelerated real per capita growth rates. Similarly, Guiso, Sapienza and Zingales (2002) examine the individual regions of Italy. They find that local financial development enhances the probability that an individual starts a business, increases industrial competition, and promotes growth of firms. And these results are stronger for smaller firms which cannot easily raise funds outside of the local area. Bertrand, Schoar and Thesmar (2004) provide firm-level evidence from France that shows the impact of 1985 deregulation eliminating

\footnotetext{
${ }^{4}$ Chosen on the basis that the US financial system is relatively free of frictions, so each US industry's use of external finance is a good proxy for its demand.
} 
government intervention in bank lending decisions fostered greater competition in the credit market, inducing an increase in allocative efficiency across firms.

Besides debates concerning the role of finance in economic development, economists have debated the relative importance of bank-based and market-based financial systems for a long time (Golsdmith, 1969; Boot and Thakor, 1997; Allen and Gale, 2000; Demirguc-Kunt and Levine, 2001c). However, research findings in this area have established that the debate matters much less than was previously thought, and that it is the financial services themselves that matter more than the form of their delivery (Levine, 2002; Demirguc-Kunt and Maksimovic, 2002; Beck and Levine, 2002). Financial structure does change during development, with financial systems becoming more market-based as the countries develop (Demirguc-Kunt and Levine, 1996 and 2001b). But controlling for overall financial development, differences in financial structure per se do not help explain growth rates. Nevertheless, these studies do not necessarily imply that institutional structure is unimportant for growth, rather that there is not one optimal institutional structure suitable for all countries at all times. Growthpromoting mixture of markets and intermediaries is likely to be determined by the legal, regulatory, political, policy and other factors that have not been adequately incorporated into the analysis or the indicators used in the literature may not sufficiently capture the comparative roles of banks and markets (Demirguc-Kunt and Levine, 2001a).

Financial development has been shown to also play an important role in dampening the impact of external shocks on the domestic economy (Beck, Lundberg and Majnoni, 2006; Aghion, Banerjee and Manova, 2005; Raddatz, 2006), although financial crises do occur in developed and developing countries alike (Demirguc-Kunt and 
Detragiache, 1998 and 1999; Kaminsky and Reinhart, 1999). ${ }^{5}$ Indeed, deeper financial systems without the necessary institutional development has been shown to lead to a poor handling or even magnification of risk rather than its mitigation, consistent with the findings of Demirguc-Kunt and Detragiache (1998), Beck, Lundberg and Majnoni (2006) and numerous country case studies discussed in Demirguc-Kunt and Detragiache (2005).

Another area of investigation where there has been recent empirical research is the impact of financial development on income distribution and poverty. Theory provides conflicting predictions in this area. Some theories argue that financial development should have a disproportionately beneficial impact on the poor since informational asymmetries produce credit constraints that are particularly binding on the poor. Poor people find it particularly difficult to fund their own investments internally or externally since they lack resources, collateral and political connections to access finance (see for example, Banerjee and Newman, 1993; Galor and Zeira, 1993; Aghion and Bolton, 1997). More generally, some political economy theories also suggest that better functioning financial systems make financial services available to a wider segment of the population, rather than restricting them to politically connected incumbents (Rajan and Zingales, 2003; Morck, Wolfenzon and Young, 2005). Yet others argue that financial access, especially to credit, only benefits the rich and the connected, particularly at early stages of economic development and therefore, while financial development may promote growth, its impact on income distribution is not clear (Lamoreaux, 1994; Haber, 2004 and 2005). Finally, if access to credit improves with aggregate economic growth and more people can afford to join the formal financial system, the relationship between

\footnotetext{
${ }^{5}$ Also see Demirguc-Kunt and Detragiache (2005) for a review of the bank crisis literature.
} 
financial development and income distribution may be non-linear, with adverse effects at early stages, but a positive impact after a certain point (Greenwood and Jovanovic,1990). In cross-country regressions, Beck, Demirguc-Kunt and Levine (2004) investigate how financial development influences the growth rate of Gini coefficient of income inequality, the growth rate of the income of the poorest quintile of society, and the fraction of the population living in poverty. The results indicate that finance exerts a disproportionately large, positive impact on the poor and hence reduces income inequality. Investigating levels rather than growth rates, Honohan (2004) shows that even at the same average income, economies with deeper financial systems have fewer poor people. ${ }^{6}$ Much more empirical research using micro datasets and different methodologies will be necessary to confirm these initial findings, and to better understand the mechanisms through which finance affects income distribution and poverty.

Taken as a whole, the empirical evidence reviewed above suggests that countries with better developed financial systems grow faster and that this growth disproportionately benefits the poorer segments of the society. Yet, financial system development differs widely across countries. What makes some countries develop growth-promoting financial systems, while others cannot? If finance is crucial for economic development, what can governments do to ensure well-functioning financial systems? I turn to these questions next.

\footnotetext{
${ }^{6}$ Also looking at levels, Clarke et al. (2003) provide further evidence that financial development is associated with lower levels of inequality.
} 


\section{Financial Development: Indicators and Historical Determinants}

Financial development is a multifaceted concept and thus difficult to measure.

Ideally, we would like indicators of how well each financial system fulfills its functions, i.e., identifies profitable projects, exerts corporate control, facilitates risk management, mobilizes savings, and eases transactions. Unfortunately, since no such measures are available across countries, I will rely on commonly used measures of financial development to illustrate cross-country differences. Table 1 reports summary statistics for indicators of financial depth, efficiency, access, size and openness by income level for over 150 countries.

Private Credit, the value of credit by financial intermediaries to the private sector divided by GDP, and Stock Market Capitalization, the value of listed shares divided by GDP, are frequently used as measures of depth for the banking system and stock markets, respectively. Private Credit captures the amount of credit channeled from savers, through financial intermediaries, to private firms. Analysts use Stock Market Capitalization to indicate the ability to mobilize capital and diversify risk. Both Private Credit and Market Capitalization increase with income (Figures 1a and 2a), although at similar levels of development there are still large differences (Figures $1 \mathrm{~b}$ and $2 \mathrm{~b}) .^{7}$ For example, while Thailand's Private Credit is over 100 percent, at similar levels of GDP per capita, Peru only has a value of 23 percent. Similarly, Malaysia’s Stock Market Capitalization is 140 percent, Costa Rica, another upper middle income country has a ratio of 10 percent.

\footnotetext{
${ }^{7}$ Also note that significant increases in financial depth not predicted by the underlying institutional improvements may signal trouble: Demirguc-Kunt and Detragiache (1998) show that credit booms often lead to crises, and Demirguc-Kunt and Maksimovic (2002) show that levels of banking and stock market development not predicted by legal efficiency and creditor rights protection do not promote firm growth.
} 
The Net Interest Margin measures the gap between what the banks pay the providers of funds and what they get from firms and other users of bank credit and it equals interest income minus interest expense divided by interest bearing assets, averaged over the banks in each country. It is frequently used to measure efficiency despite the fact that differences in net margins may reflect differences in bank activities rather than differences in efficiency or competition. Net Interest Margin tends to decline with a country's income, suggesting bank efficiency improves with development (Figure 3a). Unlike measures of depth, dispersion in efficiency figures tends to be higher at the lower end of the income distribution (Figure $3 \mathrm{~b}$ and Table 1).

While measures of financial depth and margins are available for a large set of countries, measures of the reach of the sector have been much more difficult to obtain across countries. Until recently, we did not have answers to simple questions like what proportion of the population has a bank account or loan. Beck, Demirguc-Kunt and Martinez Peria (2005) is the first study to develop cross-country measures of access to and use of banking services. One of their indicators, Number of loans per capita, captures the use of credit services, with higher numbers indicating mode widespread use. Figure 4a shows that use of bank credit increases drastically with income. But differences within income groups are also large: while there are 770 bank loans per 1000 people in Poland, there are only 94 in Venezuela (Figure 4b and Table 1). Further research in this area is moving in the direction of developing better indicators of access to different financial services, using surveys both at the financial institution and household level. 
Another interesting indicator is the size of the financial system. For example measured by the Liquid Liabilities of the financial system (M2), about one third of all the countries have financial systems smaller than $\$ 1$ billion, and another third have systems smaller than $\$ 10$ billion (Figure 5b). Leaving outliers like China or India aside, most developing countries have very small financial systems (Figure 5a). This underlines the importance of domestic policy actions to maximize each country's capacity to secure the best provision of financial services from the global marketplace.

The last indicator, Freedom in Banking and Finance index, is a measure of openness of the banking industry. It is constructed by the Heritage Foundation and captures the extent of government involvement in the financial sector through ownership and control of financial institutions, quality of regulation and supervision, existence of interest controls, activity restrictions or directed lending, and the ability of foreign institutions to operate freely. The index ranges from 1 to 5 , with higher ratings indicating less openness and freedom. Lower income countries allow their banks less freedom in general, compared to more developed countries. But, for example comparing two low-income countries, Cote d'Ivoire has a much more liberalized banking system with a score of 2.5, whereas in Uzbekistan government still has heavy involvement in the financial sector and allows no foreign entry, getting the highest possible score of 5 (Figure 6a,b).

The above analysis illustrates that financial systems vary widely with respect to all dimensions. Even at similar levels of development, there are significant differences in their size, depth, efficiency, breath and openness. Given the important role finance plays in promoting development, there is a growing body of research that examines 
determinants of financial development. One area of this line of research focuses on historical determinants of financial development and studies the legal, political, cultural, ethnic and geographic differences across countries that may shape development of financial institutions and markets.

La Porta et al. (1997 and 1998) stress that differences in legal traditions shape the laws and enforcement mechanisms that protect the rights of outside investors, thus influencing financial development. Focusing on the differences between the two most influential legal traditions, the British Common law and the French Civil law, this view holds that legal traditions differ in terms of the priority they attach to protecting the rights of private investors against the state. Beck, Demirguc-Kunt and Levine (2003b and 2005) also show that legal system adaptability is crucial and more flexible legal systems do a better job at meeting the continuously changing financial needs of the economy and promoting financial development.

Haber (2004), Pagano and Volpin (2001), Rajan and Zingales (2003) focus on how political economy forces shape national policies toward financial development and influence and change the political power of entrenched incumbents. According to this view, closed political systems are more likely to impede the development of financial systems that promote competition and threaten entrenched powers than open political systems. This is because centralized and powerful states are more responsive to and efficient at implementing policies that protect the interests of the elite than decentralized and competitive political systems with an assortment of checks and balances.

Stulz and Williamson (2003) emphasize the role of religion and culture in influencing development of institutions. Many scholars argue that religion shapes 
national views regarding institutions, including financial institutions. For example, it is said that Catholic Church fosters "vertical bonds of authority" rather than "horizontal bonds of fellowship.” This view suggests that Catholic and Muslim countries tend to develop cultures that maintain control, limiting competition and private property rights. Alesina et al. (2003) and Easterly and Levine (2003) focus on ethnic differences, instead. They argue that in highly ethnically diverse economies, the group that comes to power tends to implement policies that expropriate resources, restrict the rights of other groups, and prevent the growth of industries or sectors that threaten the ruling group.

Others stress the role of initial geographic endowments in determining attitudes towards development of different institutions (Engerman and Sokoloff, 1997; Acemoglu, Johnson and Robinson, 2001). Acemoglu et al. (2001) focus on the disease environment and argue that the degree to which Europeans can settle in a land influenced the choice of colonization strategy with long lasting implications on institutions. Engerman and Sokoloff (1997) focus on the geographic endowments and study the differential development of institutions in North America. They argue that the geographic conditions in the North which favored production of wheat and maize fostered a large middle class with egalitarian institutions, whereas the conditions in the South which led to the production of rice and sugarcane also led to the rise of a powerful elite and more closed institutions.

Beck, Demirguc-Kunt and Levine (2003a) investigate the relative importance of these historical determinants of financial development and find that differences in initial endowments and legal origins are robustly associated with development of financial institutions and markets. Thus, countries with common law origins with better protection 
of outside investors were more likely to develop financial institutions. But colonization strategy also mattered: Tropical environments, inhospitable to European settlement, were more likely to foster extractive institutions as opposed to institutions that promote financial development. ${ }^{8}$

Perhaps most important from a policy viewpoint however, is the government's role in building effective financial systems. In the next section, I review the role of regulations and economic policies in influencing financial development.

\section{Government's Role in Making Finance Work}

Although finance thrives on market discipline and fails to contribute to development process effectively in the presence of interventionist policies, governments do have a very important role to play in promoting well-functioning financial systems. Specifically, governments can help greatly through providing a stable political and macroeconomic environment, fiscal discipline and good governance; well-functioning legal and information infrastructure; and strong regulation and supervision that enable greater market monitoring without distorting the incentives of market participants. Governments can also improve the contestability and efficiency of financial systems by avoiding ownership of financial institutions, and liberalizing their systems including allowing foreign entry. Government policies can also help in efforts to facilitate broad access to financial services. Below, I discuss each of these areas and, where applicable, pros and cons of different policies.

\footnotetext{
${ }^{8}$ Ayyagari, Demirguc-Kunt and Maksimovic (2006a, b) instead focus on property rights protection and show that legal origin is not a robust determinant whereas ethnic fractionalization is.
} 


\section{IIIa. Political and Macroeconomic Environment}

Even if historical factors are favorable to financial development, political turmoil may lead to macroeconomic instability and deterioration in business conditions. Civil strife and war destroys capital and infrastructure, and expropriations may follow military takeovers. Corruption and crime thrive in such environments, increasing cost of doing business and creating uncertainty about property rights. Detragiache, Gupta and Tressel (2005) show that for low-income countries political instability and corruption have a detrimental effect on financial development. Investigating the business environment for 80 countries using firm level survey data, Ayyagari, Demirguc-Kunt and Maksimovic (2005) find that political instability and crime are important obstacles to firm growth, particularly in African and Transition countries. Further, Beck, Demirguc-Kunt and Maksimovic (2005) show that the negative impact of corruption on firm growth is most pronounced for smaller firms.

Given a stable political system, well functioning financial systems also require fiscal discipline and stable macroeconomic policies on the part of governments. Monetary and fiscal policies affect the taxation of financial intermediaries and provision of financial services (Bencivenga and Smith, 1992; Huybens and Smith, 1999; Roubini and Sala-i-Martin, 1992 and Roubini and Sala-i-Martin, 1995). Often large financing requirements of governments crowd out private investment by increasing the required returns on government securities and absorbing the bulk of the savings mobilized by the financial system. Bank profitability does not necessarily suffer given the high yields on these securities, but the ability of the financial system to allocate resources efficiently is severely curtailed. Empirical studies have also shown that countries with lower and more 
stable inflation rates experience higher levels of banking and stock market development (Boyd, Levine and Smith, 2001) and high inflation and real interest rates are associated with higher probability of systemic banking crises (Demirguc-Kunt and Detragiache, 1998 and 2005).

\section{IIIb. Legal and Information Infrastructure}

Financial systems also require developed legal and information infrastructures to function well. Firms' ability to raise external finance in the formal financial system is quite limited if the rights of outside investors are not protected. Outside investors are reluctant to invest in companies if they will not be able to exert corporate governance and protect their investment from controlling shareholders/owners or the management of the companies. Thus, protection of property rights and effective enforcement of contracts are critical elements in financial system development.

Empirical evidence shows firms are able to access external finance in countries where legal enforcement is stronger (La Porta et al., 1997; Demirguc-Kunt and Maksimovic, 1998; Beck, Demirguc-Kunt and Maksimovic, 2005), and that better creditor protection increases credit to the private sector (Djankov, McLiesh and Shleifer, 2005). More effective legal systems allow more flexible and adaptable conflict resolution, increasing firms’ access to finance (Djankov et al., 2003; Beck, DemirgucKunt and Levine, 2005). In countries where legal systems are more effective, financial systems have lower interest rate spreads and are more efficient (Demirguc-Kunt, Laeven and Levine, 2004; Laeven and Majnoni, 2005).

Timely availability of good quality information is equally important, since this helps reduce information asymmetries between borrowers and lenders. The collection, 
processing and use of borrowing history and other information relevant to household and small business lending - credit registries - have been rapidly growing in both the public and private sectors (see Miller, 2003, for an overview). Computer technology has also greatly improved the amount of information that can be analyzed to assess creditworthiness, such as through credit scoring techniques. Governments can play an important role in this process, and while establishment of public credit registries may discourage private entry, in several cases it has actually encouraged private registries to enter in order to provide a wider and deeper range of services. Governments are also important in creating and supporting the legal system needed for conflict resolution and contract enforcement, and strengthening accounting infrastructures to enable financial development.

Empirical results show that the volume of bank credit is significantly higher in countries with more information sharing (Jappelli and Pagano, 2002; and Djankov, McLeish and Shleifer, 2005). Firms also report lower financing obstacles with better credit information (Love and Mylenko, 2003). Detragiache, Gupta and Tressel (2005) find that better access to information and speedier enforcement of contracts are associated with deeper financial systems even in low-income countries. Indeed, compared to high income countries, in lower income countries it is credit information more than legal enforcement that matters (Djankov et al., 2005).

\section{IIIc. Regulation and Supervision}

For as long as there have been banks, there have also been governments regulating them. While most economists agree that there is a role for government in the regulation and supervision of financial systems, the extent of this involvement is an issue 
of active debate (Barth, Caprio and Levine, 2006; Beck, 2006). One extreme view is the laissez-faire or invisible-hand approach, where there is no role for government in the financial system, and markets are expected to monitor and discipline financial institutions. This approach has been criticized for ignoring market failures as depositors, particularly small depositors, often find it too costly to be effective monitors. ${ }^{9}$ Thus, governments often act as delegated monitors for depositors, exploiting economies of scale to overcome costly information problems.

On the other extreme is the complete interventionist approach, where government regulation is seen as the solution to market failures (Stigler, 1971). According to this view, powerful supervisors are expected to ensure stability of the financial system and guide banks in their business decisions through regulation and supervision. This view relies on two crucial assumptions. First, that governments know better than markets, and second, that they act in the best interests of the society. To the extent that officials generally have limited knowledge and expertise in making business decisions and can be subject to political and regulatory capture, these assumptions will not be valid (Becker and Stigler, 1974; Haber et al. 2003).

Between the two extremes lies the private empowerment view of financial regulation. This view simultaneously recognizes the potential importance of market failures which motivate government intervention, and political/regulatory failures, which suggest that supervisory agencies do not necessarily have incentives to ease market failures. The focus is on enabling markets, where there is an important role for

\footnotetext{
${ }^{9}$ Small depositors have to be protected, but banks also need to be protected against runs by uninformed depositors that may precipitate forced liquidations. Further, market imperfections may also prevent optimal resource allocation, as powerful banks may extract rents from firms, reducing their incentives to undertake profitable investments. See Levine (2005) for further discussion.
} 
governments in enhancing the ability and incentives of private agents to overcome information and transaction costs, so that private investors can exert effective governance over banks. Consequently, the private empowerment view seeks to provide supervisors with the responsibility and authority to induce banks to disclose accurate information to the public, so that private agents can more effectively monitor banks (Barth, Caprio and Levine, 2006).

Empirical evidence overwhelmingly supports the private empowerment view. While there is little evidence that empowering regulators enhances bank stability, there is evidence that regulations and supervisory practices that force accurate information disclosure and promote private sector monitoring boost the overall level of banking sector and stock market development (Barth, Caprio and Levine, 2006).

Beck, Demirguc-Kunt and Levine (2006) show that bank supervisory practices that force accurate information disclosure ease external financing constraints of firms, while countries that empower their official supervisors actually make external financing constraints more severe by increasing the degree of corruption in bank lending. ${ }^{10}$ Consistent with these findings, Demirguc-Kunt, Detragiache and Tressel (2006) investigate compliance with Basel Core Principles of regulation and supervision and show that only information disclosure rules have a significant impact on bank soundness. Finally, Detragiache, Gupta and Tressel (2005) find little significant impact of regulatory and supervisory practices on financial development of low-income countries. Where

\footnotetext{
${ }^{10}$ La Porta et al. (2006) find a similarly positive effect of private monitoring and disciplining for stock market development. Laws and liability rules that mandate disclosure and facilitate private enforcement promote stock market development, while there is little evidence for a positive effect of public enforcement.
} 
there is significance, greater supervisory powers seem to be negatively associated with financial depth.

Related to the debate on different approaches for regulation and supervision, is the important debate on whether prudential regulation and safety nets designed for developed countries can be successfully transplanted to developing countries. Research shows that financial sector policy which is considered appropriate in advanced economies can prove ineffective or even counterproductive in weak institutional environments of developing countries. For example, powerful regulators are not significantly associated with increased corruption in banking in countries with strong institutions that provide checks and balances, but lead to greater capture and corruption in lower-income countries. However, although empowering the markets and focusing on information disclosure are policies that promote bank stability most effectively in countries where there is strong rule of law, we do not observe negative effects of such policies even in low-income countries (Beck, Demirguc-Kunt and Levine, 2006). ${ }^{11}$ For developing countries, these results have important implications for which aspects of the Basel II accord (which was designed for and by regulators in advanced economies) to adopt and over what time period. In particular, the complicated rules and procedures for determining bank capital adequacy pre-suppose expertise and governance conditions which simply do not exist in most low-income countries.

Similarly, research has questioned safety net design, particularly adoption of deposit insurance in developing countries by highlighting the potential costs of explicit schemes -lower market discipline, higher financial fragility, and lower financial

\footnotetext{
${ }^{11}$ Consistent with these results, Demirguc-Kunt, Detragiache and Tressel (2006) show that compliance with the information disclosure rules of Basel Core Principles promotes bank stability where there is strong rule of law.
} 
development - in countries where complementary institutions are not strong enough to keep these costs under control (Demirguc-Kunt and Kane, 2002; Demirguc-Kunt and Detragiache, 2002; Demirguc-Kunt and Huizinga, 2004; Cull, Senbet and Sorge, 2005). These findings are particularly important for lower income countries with underdeveloped institutions. For example, Detragiache, Gupta and Tressel (2005) also find that presence of an explicit deposit insurance system does not lead to more deposit mobilization in low-income countries; to the contrary it is associated with lower levels of deposits. $^{12}$

\section{IIId. Contestability and Efficiency}

Policymakers around the world frequently express concern about whether their countries’ bank competition policies are appropriately designed to produce wellfunctioning and stable banks. Globalization and the resulting consolidation in banking have further spurred interest in this issue, leading to an active public policy debate. Competition policies in banking may involve difficult trade-offs. While greater competition may enhance the efficiency of banks with positive implications for economic growth, greater competition may also destabilize banks with costly repercussions for the economy.

Recent research has shown that contrary to conventional wisdom, there are no difficult trade-offs when it comes to bank competition. Greater competition - as captured by lower entry barriers, fewer regulatory restrictions on bank activities, greater banking freedom, and better overall institutional development - is good for efficiency, good for

\footnotetext{
${ }^{12}$ Using a sample of developed and developing countries, Cecchetti and Krause (2004) also find that explicit deposit insurance results in less credit provision to the private sector.
} 
stability, and good for firms' access to finance (Berger et al., 2004). ${ }^{13}$ Indeed, regulations that interfere with competition make banks less efficient, more fragile, and reduce firms’ access to finance. Thus, it is a good idea for governments to encourage competition in banking by reducing the unnecessary impediments to entry and activity restrictions. Similarly, improving the institutional environment and allowing greater freedoms in banking and economy in general would lead to desirable outcomes.

Ownership is another important dimension of competition in banking. As I discuss further in sections IIIe and f, research shows that while foreign banking is associated with generally positive outcomes, state ownership is associated with higher margins, greater fragility and less access. These results highlight the importance of removing impediments to foreign entry and provide further justification for bank privatization policies. Finally, bank concentration, which has been the focus of much policy discussion, is not a good proxy for the overall competitive environment per se and its impact often depends on the existing regulatory and institutional framework. Hence governments would do better to focus on improving the underlying regulatory and institutional environment (as discussed in sections IIIb and c) and ownership structure to promote contestable financial systems, rather than trying to reduce concentration levels in banking.

IIIe. Government Ownership of Financial Institutions

Policymakers in many countries have felt the need to retain public ownership of banks. However, research has shown that government ownership of banks everywhere, but especially in developing countries, lead to lower levels of financial development,

\footnotetext{
${ }^{13}$ Also see Beck, Demirguc-Kunt and Maksimovic (2004), Beck, Demirguc-Kunt and Levine (2006), Claessens and Laeven (2004), and Demirguc-Kunt, Laeven and Levine (2004).
} 
more concentrated lending and lower economic growth, and greater systemic fragility (La Porta et al., 2002; Barth, Caprio and Levine, 2004). The inefficient allocation of credit by state-owned banks to politically-favored and commercially unviable projects frequently necessitates costly recapitalizations (Cole, 2005; Dinc, 2005). Thus, empirical evidence shows that the ownership of financial firms is an area where the public sector tends not to have a comparative advantage; such ownership weakens the financial system and the economy.

However, privatization also entails risks and needs careful design. Studies of privatization processes suggest the preferred strategy is moving slowly but deliberately with bank privatization, while preparing state banks for sale and addressing weaknesses in the overall incentive environment. On average, bank privatization tends to improve performance over continued state ownership, and there are advantages to full rather than partial privatizations, and in weak institutional environments selling to a strategic investor and inviting foreign interests to participate in the process increase the benefits (see Clarke, Cull, Shirley, 2005). Privatization, however, is not a panacea, and privatizing banks without addressing weaknesses in the underlying incentive environment and market structure will not lead to a deeper and more efficient financial system.

\section{IIIf. Financial Liberalization}

As illustrated above, in comparison with the scale of global finance, financial systems in individual developing countries are often very small. Small financial systems underperform because they suffer from concentration of risks, cannot exploit economies of scale and are thus more vulnerable to external shocks (Bossone, Honohan and Long, 
2001). Theoretically, these countries fall short of minimum efficient scale and have much to gain by liberalizing and sourcing some of their financial services from abroad.

There is a very large literature on macroeconomic and international financial issues which are outside the scope of this paper. In this section I limit my discussion to (a) the impact of financial liberalization on financial development and the importance of sequencing liberalization and institutional reforms; (b) the impact of exchange rate regime on financial fragility; and the impact of (c) foreign entry and (d) international capital flows on financial development.

Financial liberalization, financial development and the sequencing of reforms. Many countries have liberalized their financial systems in the 1980s and 1990s with mixed results. Liberalization, including deregulation of interest rates and more relaxed entry policies, often led to significant financial development, particularly in countries where there was significant repression, but the enthusiasm with which financial liberalization was adopted in some countries in the absence of or slow implementation of institutional development also left many financial systems vulnerable to systemic crises (Demirguc-Kunt and Detragiache, 1999). Poor sequencing of financial liberalization in a poorly prepared contractual and supervisory environment contributed to bank insolvencies as banks protected by implicit and explicit government guarantees aggressively took advantage of new opportunities to increase risk, without the necessary lending skills. Banking crises in Argentina, Chile, Mexico and Turkey in the 1980s and 1990s have been attributed to these factors (Demirguc-Kunt and Detragiache, 2005).

On the other hand, many Sub-Saharan African countries that have also liberalized their interest rates and credit allocation and privatized their institutions by allowing entry 
of reputable foreign banks did not suffer instability but from lower intermediation and in some cases lower access to financial services. Some of this was due to the absence of an effective contractual and informational framework (See Beck and Fuchs, 2004). This has also resulted in claims of failed liberalizations in these countries and calls for greater government intervention in the financial sector. ${ }^{14}$ Both of these experiences with financial liberalization underline the importance of sequencing liberalization and institutional improvements.

Impact of exchange rate policy on financial fragility. The choice of an appropriate exchange rate regime for developing countries is another issue of active debate. ${ }^{15}$ One of the reasons this is an important issue is because the choice of exchange rate regime may influence the extent to which the impact of external shocks affect financial stability. For instance, flexible exchange rates may have a stabilizing effect on the financial system since the exchange rate can absorb some of the real shocks to the economy (Mundell, 1961). Flexible regimes may also curtail the tendency of countries to over-borrow in foreign currency and discourage banks from funding dangerous lending booms through external credit (Eichengreen and Hausmann, 1999). Further, with a fixed exchange rate (and even more so with a currency board), lender of last resort operations are severely limited, since domestic monetary expansion risks undermining confidence in the currency peg.

On the other hand, a commitment to a currency peg may reduce the probability of banking crises by disciplining policymakers (Eichengreen and Rose, 1998). The lack of an effective lender of last resort may also discourage risk-taking by bankers, decreasing

\footnotetext{
${ }^{14}$ However, after a slow start, credit growth is accelerating across Africa, and there has also been a catchup in access, often through growth of cooperatives and other microfinance institutions.

${ }^{15}$ See Yagci (2006) in this volume for an extensive discussion.
} 
the likelihood of a banking crisis. Finally, developing countries are often plagued by lack of credibility and limited access to international markets, and suffer from more pronounced effects of exchange rate volatility due to their high liability dollarization. Thus, the additional transparency and credibility associated with fixed exchange rates may insulate a country from contagion (Calvo, 1999).

Empirically, Arteta and Eichengreen (2002) find that countries with fixed and flexible exchange rates are equally susceptible to banking crises. In contrast, Domac and Martinez Peria (2003) find that adopting a fixed exchange rate regime diminishes the likelihood of a banking crisis in developing countries. However, once a crisis occurs, its economic cost is larger under a fixed exchange rate.

Studies on the impact of dollarization on financial fragility similarly reveal mixed evidence. Dollarization is a symptom of weak domestic currencies and volatile real exchange rates and thus may be associated with fragility. Arteta (2003) investigates the impact of deposit and credit dollarization for a large number of developing and transition countries and finds no evidence that dollarization increases fragility. De Nicolo, Honohan and Ize (2003) perform a similar test but measure fragility using average Zscores (measuring the distance to default for the banking system, which is different from the actual occurrence of a systemic crisis) and non-performing loans across a large number of countries. In contrast to Arteta's results, they find that dollarization is positively related to both measures of bank fragility. More research is needed in these areas to guide the on-going policy discussion on the impact of exchange rate policies. Impact of foreign entry. With financial liberalization, more and more developing economies also allow entry of foreign financial institutions. While governments have 
worried about whether allowing foreign banks to take a large ownership share in the banking system could damage financial and economic performance, the bulk of the empirical research in this area, particularly drawing on the experience of Latin American and Eastern European countries, suggests that facilitating entry of reputable foreign institutions to the local market should be welcomed. Foreign banks bring competition, improve efficiency, lift the quality of the financial infrastructure and expand access (Claessens, Demirguc-Kunt and Huizinga, 2001; Clarke, Cull and Martinez Peria, 2001). ${ }^{16}$

As the African experience illustrates, foreign bank entry cannot guarantee rapid financial development in the absence of sound contractual and informational weaknesses, however. Such weaknesses can prevent low-income countries from reaping full benefits of opening their markets to foreign providers of financial services, and can potentially explain the finding that greater foreign bank penetration is associated with lower levels of financial development (Detragiache, Tressel, Gupta, 2006). ${ }^{17}$ However, addressing these weaknesses is likely to allow foreign banks to act as an important catalyst for the sort of financial development that promotes growth. Impact of international capital flows. While there is consensus that liberalizing financial systems facilitates their development, there are also concerns that this leaves

\footnotetext{
${ }^{16}$ While in some countries like Pakistan, foreign banks have been shown to lend less to smaller more opaque borrowers because they rely on hard information (Mian, 2003), evidence from Eastern Europe has shown that foreign banks eventually go down market increasing small business lending (De Haas and Naaborg, 2005). This is consistent with recent research that shows as new transaction-based lending techniques have been developed, where large foreign institutions have greater advantage, relationship lending, thus small, domestic institutions have become less important for SME lending (Berger and Udell, 2006).

${ }^{17}$ Another explanation why cross-country correlations between foreign bank penetration and financial development may be negative in low-income countries is that in most of those countries foreign bank entry was through privatization of failed government banks.
} 
them more open to volatility and crises. ${ }^{18}$ As discussed above, one way of containing such volatility is stronger fundamentals, hence proper sequencing of reforms. ${ }^{19}$ Policy discussion has also focused on proper design of capital controls, which could prevent or mitigate the effects of sudden shifts in foreign capital. Controls can take the form of restrictions on outflows; restrictions on aggregate inflows; restrictions on short-term flows (a la Chile); or a Tobin tax, aimed at imposing a small uniform tax on all foreign exchange transactions, regardless of their nature.

There is a large literature on the effects of capital controls, but overall, these empirical studies suggest that these controls work at best temporarily, with the effects diminishing over time, and are not effective in preventing spillovers from very large shocks (Kaminsky and Schmukler, 2001).

Besides debt and equity flows, workers’ remittances, funds received from migrants working abroad, have grown steadily in recent years becoming the second largest source of external finance after foreign direct investment. Furthermore, unlike other capital flows, remittances tend to be stable even during periods of economic downturns and crises. Recent research also provides evidence that remittances do promote financial development (Aggarwal, Demirguc-Kunt and Martinez Peria, 2006). Other studies emphasize the importance of financial development in allowing countries to make the most out of capital flows. For example, Hermes and Lensink (2003) show that

\footnotetext{
${ }^{18}$ Opening up allows firms to raise resources abroad but Levine and Schmukler (2005) show that it may also reduce the trading activity of these firms on domestic stock exchanges, negatively affecting the liquidity of other firms that do not go abroad. However, Ferreira and Matos (2005) show that with increased cross-listing, foreign ownership of shares traded on the local exchanges also increase.

${ }^{19}$ Note that studies suggest volatility tends to decrease in the long run, with more integrated markets having lower volatility due to better diversification and development of the financial sector (Bekaert and Harvey, 2003). However, liberalization does also increase the probability of crisis (Demirguc-Kunt and Detragiache, 1999).
} 
a more developed financial system positively contributes to the process of technological diffusion associated with foreign direct investment.

\section{IIIg. Facilitating Access}

Access to financial services has increasingly been receiving greater emphasis over the recent years, becoming a focal part of the overall development agenda. One reason is the accumulating evidence on the importance of finance for growth, and the belief that limited access to finance is a contributor to not being able to escape poverty. Another is the observation that small enterprises and poor households face much greater obstacles in their ability to access finance all around the world, but particularly in developing countries.

What does access to finance mean? There are many dimensions of access, including availability, cost, and range and quality of services being offered. Morduch (1999) defines these dimensions as (a) reliability, whether finance is available when it is

needed or desired; (b) convenience, how easy it is to access finance; (c) continuity, ability to access finance repeatedly; and (d) flexibility, whether the product is tailored to the needs of the household or enterprise.

While there is much data on financial sector development more broadly, there is very little data on usage and access to finance, both for households and firms. Hence, there is also very limited analysis on the impact of access to finance on economic development. Research using firm level survey data suggests that financing obstacles are the most constraining among different barriers to growth (Ayyagari, Demirguc-Kunt and Maksimovic, 2005). Financing obstacles are also found to be highest and most constraining for the growth of smaller firms (Beck, Demirguc-Kunt and Maksimovic, 
2005). At the household level, lack of access to credit is shown to perpetuate poverty because poor households reduce their children's education (Jacoby, 1994; Jacoby and Skoufias, 1997). Similarly, Dehejia and Gatti (2003) find that child labor rates are higher in countries with under-developed financial systems, while Beegle et al. (2003) show that transitory income shocks to greater increases in child labor in countries with poorly functioning financial systems. A better understanding of what the chief obstacles to improving access are, and access to which type of financial services has the greater impact on reducing poverty and promoting growth, will need to wait for availability of better data in this area.

There are many different reasons why the poor do not have access to finance loans, savings accounts, insurance services. Social and physical distance from the formal financial system may matter. The poor may not have anybody in their social network who knows the various services that are available to them. Lack of education may make it difficult for them to overcome problems with filling out loan applications, and the small number of transactions they are likely to undertake may make the loan officers think it is not worthwhile to help them. As financial institutions are likely to be in richer neighborhoods, physical distance may also matter, banks simply may not be near the poor (Beck and De la Torre, 2006). Specifically for access to credit services, there are two important problems. First, the poor have no collateral, and cannot borrow against their future income because they tend not to have steady jobs or income streams to keep track of. Second, dealing with small transactions is costly for the financial institutions. Ceilings on the rates financial institutions can charge backfire and limit access to the poor even more. 
Microfinance -specialized institutions that serve the poor - tries to overcome these problems in innovative ways. Loan officers come from similar social status as the borrowers and go to the poor instead of waiting for the poor to come to them. Microcredit also involves education as much as it provides credit. Group lending schemes not only improve repayment incentives and monitoring through peer pressure, but they are also a way of building support networks and educating borrowers.

Has microfinance fulfilled its promise? Microfinance allows poor people to have more direct access, but development of microfinance around the world has been very non-uniform, with significant penetration rates only in a few countries like Bangladesh, Indonesia and Thailand (Honohan, 2004). Group lending is very costly since labor cost per dollar of transactions needs to be high by design. The most controversial aspect of microfinance, however, has been the extent of subsidy required to provide this access. Overall, the microfinance sector remains heavily grant and subsidy dependent. Skeptics question whether microfinance is the best way to provide those subsidies and point out that development of mainstream finance is a more promising way to reach the poor and alleviate poverty in significant ways.

There are also good political economy reasons why we should not focus on the poor and ask how we can make microfinance more viable, but instead ask how financial services can be made available for all (Rajan, 2006). ${ }^{20}$ The poor lack the political clout to demand better services, and subsidies may spoil the credit culture. By defining the issue more broadly to include the middle class who often also lack access, would make it more likely that promotion of financial assess will be made a priority.

\footnotetext{
${ }^{20}$ Rajan (2006) argues “...let’s not kill the microfinance movement with kindness. If we want it to become more than a fad...it has to follow the clear and unsentimental path of adding value and making money. On that path lies the possibility of a true, and large-scale escape from poverty.”
} 
What can governments do to promote access? First and foremost, governments can further access by making and encouraging infrastructure improvements. Better legal, information, payments systems, distribution and other structures can allow technology to bring down transaction costs. Research shows that small firms and firms in countries with poor institutions use less external finance, especially less bank finance, and that other types of finance are imperfect substitutes (Beck, Demirguc-Kunt and Maksimovic, 2005). For example, at the household level, giving each individual a national identification number and creating credit registries where lenders share information about their clients' repayment records would help since all borrowers could then borrow using their future access to credit as collateral (Rajan, 2006).

Government regulation can also help. Removal of interest ceilings, or usury laws, would allow institutions to charge the rates that they need to be profitable and improve access. These regulations end up hurting the very poor they are trying to protect as the supply of these services completely dry up. Anti-predatory lending or truth in lending requirements is also very important since households may also be forced into overborrowing by unscrupulous lenders. Reducing costs of registering and repossessing collateral is crucial. In Brazil for example, inability to repossess property has contributed to the cost of the housing finance program, keeping the mortgage rates too high to be affordable for the poor. Anti-discrimination policies may also help against cases of active or passive discrimination against the poor or different ethnic groups.

Financial regulations can also prevent the emergence of institutions better suited to the needs of lower income households or smaller firms. Rigid chartering rules, high capital adequacy requirements, very strict accounting requirements may reduce the ability 
of institutions to serve the poorer segments of the society. As many households are interested in savings services but not in credit services, considering and regulating savings mobilization separately from credit services may be helpful (Claessens, 2005). For example in South Africa, extension of bank regulation and supervision to microfinance institutions reduced their capacity to offer their services profitably (Glaessner et al. 2004).

Governments can also be instrumental in facilitating innovative technologies to improve access. For example in Mexico, a program developed by Nafin, a government development bank, allows many small suppliers to use their receivables from large creditworthy buyers to receive working capital financing (Klapper, 2006). This type of trade finance is called reverse factoring and effectively allows small firms to borrow based on the creditworthiness of their buyers, allowing them to borrow more at cheaper rates. ${ }^{21}$

Governments can also opt to stimulate access more directly. The US Treasury's Electronic Transfer Accounts (ETAs) to increase use of bank accounts, US Community Reinvestment Act (CRA) to improve access to credit services, legal measures adopted by the UK, France, Sweden, and Ireland among others, are such examples. However, there is little consensus on the success of those schemes (Peachey and Roe, 2004; Claessens, 2005) and whether they can be replicated in developing countries. The experiences with credit extensions, especially to improve the maturity structure of debt and reach the SMEs, are extensive in both developed and developing countries. However, both the rationale for and effectiveness of those interventions are much more doubtful (see Caprio and Demirguc-Kunt, 1997; Beck and Demirguc-Kunt, 2006).

\footnotetext{
${ }^{21}$ Also see Berger and Udell (2006) for a discussion of different innovative technologies that can expand access of small firms even in the absence of a strong institutional environment. De la Torre and Schmukler (2005) includes other such public-private partnership examples of expanding access.
} 
Last but perhaps most importantly, governments can improve access by increasing competition in the financial sector. As financial institutions find their traditional business coming under competition, they seek out new lines of profitable opportunities, including lending to the SMEs and the poor. Given the right incentives, private sector can develop and make use of new technologies - like credit scoring - to reach the underserved segments. Foreign banks' role in improving the competition environment and improving access is important. There is accumulating evidence that foreign banks can enhance access (Clarke et al, 2001 and 2003). ${ }^{22}$ Indeed, multinational banks have been leading the way in expanding access all around the world. ${ }^{23}$

\section{Challenges for Low-Income Countries}

Should all countries follow these recommendations? While the general messages will not be dissimilar, the directions in which financial sector needs improvement in different countries will be based on their initial conditions (World Bank, 2001). These reforms are the most challenging for low-income countries, where the legacy of financial repression and state ownership has generally hampered the development of a vigorous private financial system, where the underlying legal and information infrastructure is weak, and achieving minimum efficient scale will be difficult. Supported by stable and sustainable macro policies, a priority for the state would be to divest itself of bank holdings and attract reputable international banks. If democracy is weak and ethnic conflict is high, a significant level of uncertainty will prevail, which will likely deter

\footnotetext{
${ }^{22}$ Also see the country examples discussed in Claessens (2005).

${ }^{23}$ Studies have found that while foreign banks with small local presence do not appear to lend much to small businesses, large foreign banks in many cases surpass large domestic banks. See for example, Sanchez et al. 2006.
} 
entry by good foreign banks. Low population density is another factor that may deter entry.

Legal and informational infrastructures are likely to be weak, and will need to be strengthened if financial systems are to function well. Transport and communications infrastructures are also essential for financial development. In financial regulation, political capture and corruption will potentially be an issue, so transparency, independence and accountability will be important. Although markets are likely to be underdeveloped and the rule of law weak, encouraging and empowering the market to participate in monitoring through education and disclosure will have longer-term pay-offs. The temptation to extend government guarantees - in the form of deposit insurance - to bolster confidence in the formal financial system should be resisted, as it has been shown to create moral hazard and backfire. The country is likely to be too small and too poor to sustain a liquid securities market, so this is an area of reform best left till after other priorities are addressed. Reducing bank concentration is not a worthy goal in itself either, the focus of policy should be improving contestability instead - through lower entry barriers, fewer restrictions on bank activities and freedoms. Improving competition in this way, coupled with institutional reforms, should increase the availability and lower the cost of credit to enterprises with good growth opportunities.

Governments would do well to remove barriers that prevent borrowers and lenders from accessing international capital markets, as institutional improvements are made. While this will increase volatility at least in the short run, it will also lead to significant benefits in terms of overall financial development. If the country is small, exploring possibilities for regional cooperation may be fruitful in improving access to 
higher quality financial services. Technological advances, facilitated by greater competition and entry of foreign know-how, can lead to promising innovations in the areas of deposits, payments, credit, and risk management, making basic financial services available to poor households and small firms.

\section{Conclusions}

A well-functioning financial system is one of the key foundations on which sustained economic development can be built. Research suggests that financial sector development plays an independent and causal role in promoting long-run economic growth. More recent evidence has also shown that finance is not only pro-growth, but also pro-poor: Well developed financial systems are associated with more rapid growth in the incomes of the poor, helping them catch up with the rest of the economy as it grows.

Yet, financial development differs sharply around the world. Even at similar levels of income, countries have very different levels of financial development. If finance is a key driver of economic development, what can governments do to promote financial development? Research so far suggests a number of important policy recommendations. First and foremost, well functioning financial systems need stable macroeconomic policies and strong legal and information systems. Making infrastructure improvements a priority is a must. Second, promoting a contestable financial sector - as characterized by lower entry barriers, fewer regulatory restrictions on bank activities, greater banking freedoms -is essential for improving depth, efficiency and access. This means reducing government ownership through careful privatization, and domestic and 
international liberalization including foreign entry. Opening up is also accompanied by risks however, particularly a higher risk of financial crisis, and therefore needs to be synchronized with improvements in institutional improvements.

Third, governments have an important role to play as regulators. But empirical evidence suggests the best approach to regulation is one which empowers the markets, rather than creating all powerful regulators who may be subject to corruption and political and industry capture. Empowering the market entails enforcing accurate and timely information disclosure and providing the right incentives for market participants to make sure they remain vigilant monitors - for example, through avoiding generous and mis-priced deposit insurance, or forbearance policies that distort risk-taking incentives. Research also questions the wisdom of transplanting First World practice to developing countries. Often regulations considered appropriate in developed economies prove ineffective or counterproductive in weaker institutional settings: Explicit deposit insurance may destabilize the very financial system it is meant to protect, and powerful supervisors may be more prone to corruption and extracting rents. Hence, the importance of institutional factors that need strengthening to support these policies.

Finally, governments have an important role to play in facilitating broad access to financial services, i.e., in expanding the availability of the range of financial services to a broader set of households, firms and sectors in the economy. A sure way of improving access is by making and encouraging infrastructure improvements. Better legal, information, payments systems, distribution and other structures can allow technology to bring down transaction costs. Promoting competition in the financial sector and allowing 
foreign institutions will also encourage the private sector to reach the under-served segments and increase the speed with which access-improving technologies are adopted.

Consumer protection rules such as anti-discrimination and anti-predatory lending regulations would help, and so would removal of interest ceilings that end up hurting the poor. Governments can also be instrumental in facilitating innovative technologies to improve access through private-public partnerships.

Finally, while the general messages will be similar, the priorities and the extent to which financial sector needs improvement in each country will depend on initial conditions, with the reforms being the most challenging for low-income countries. 


\section{References}

Acemoglu, D., Johnson, S., and Robinson, J.A. 2001. “The Colonial Origins of Comparative Development: An Empirical Investigation.” American Economic Review 91, 1369-1401.

Aggarwal, R., Demirguc-Kunt, A. and Martinez Peria, M. 2006. "Do Remittances Promote Financial Development?” Evidence from a Panel of Developing Countries.” World Bank mimeo.

Aghion, P., Angeletos, M., Banerjee, A., Manova, K. 2004. "Volatility and growth: The role of financial development.” Department of Economics, Harvard University mimeo.

Aghion, P., and Bolton, P. 1997. "A Trickle-Down Theory of Growth and Development with Debt Overhang.” Review of Economic Studies 64, 151-172.

Alesina, A., Devleeschauwer, A., Easterly, W., Kurlat, S., and Wacziarg, R. 2003. “Fractionalization.” Journal of Economic Growth 8(2).

Allen, F., and Gale, D. 2000. Comparing Financial Systems, MIT Press, Cambridge, MA.

Arteta, C. 2003. “Are Financially Dollarized Countries More Prone to Costly Crises?” International Finance Discussion Paper, Board of the Governors of the Federal Reserve System, No. 763.

Arteta, C. and Eichengreen, B. 2000. "Banking Crises in Emerging Markets: Presumptions and Evidence.” In: Blejer, M. and Skreb, M. (eds.), Financial Policies in Emerging Markets. Cambridge, MA:MIT Press.

Ayyagari, M., Demirguc-Kunt, A. and Maksimovic, M. 2005. "How Important Are Financing Constraints? The Role of Finance in the Business Environment." World Bank, mimeo.

Ayyagari, M., Demirguc-Kunt, A., and Maksimovic, V. 2006a. "How Well Do Institutional Theories Explain Firms' Perceptions of Property Rights?" Review of Financial Studies, forthcoming.

Ayyagari, M., Demirgüç-Kunt, A., Maksimovic, V., 2006b. "What Determines Protection of Property Rights? An Analysis of Direct and Indirect Effects," World Bank mimeo.

Banerjee, A., and Newman, A. 1993. "Occupational Choice and the Process of Development.” Journal of Political Economy 101, 274-298. 
Barth, J.R., Caprio Jr., G., and Levine, R. 2004. "Bank regulation and supervision: What Works Best?” Journal of Financial Intermediation 13, 205-248.

Barth, J., Caprio, G., and Levine, R. 2006. Rethinking Bank Regulation - 'Till Angels Govern. Cambridge University Press.

Beck, T. 2006 "Creating an Efficient Financial System: Challenges in a Global Economy.” World Bank mimeo.

Beck, T. and A. de la Torre, 2006. "The Basic Analytics of Access to Financial Services,” World Bank mimeo.

Beck, T., and Demirguc-Kunt, A. 2006. "Small and Medium-Sized Enterprises: Access to Finance as Growth Constraint.” Journal of Banking and Finance, forthcoming.

Beck, T., Demirguc-Kunt, A., Laeven, L., and Levine, R. 2004. "Finance, Firm Size, and Growth." World Bank Policy Research Working Papers 3485.

Beck, T., Demirgüç-Kunt, A., Levine, R. 2006. “Bank Supervision and Corruption in Lending”. Journal of Monetary Economics, forthcoming.

Beck, T., Demirguc-Kunt, A., and Levine, R. 2006. "Bank Concentration, Competition, and Crises: First Results.” Journal of Banking and Finance, forthcoming.

Beck, T., Demirgüç-Kunt, A., and Levine, R. 2005. "Law and Firms' Access to Finance.” American Law and Economics Review 7, 211-252.

Beck, T., Demirgüç-Kunt, A., Levine, R. 2004. "Finance, inequality and poverty: Crosscountry evidence”. Mimeo. University of Minnesota (Carlson School of Management).

Beck, T., Demirgüç-Kunt, A., and Levine, R. 2003. “Law, Endowments, and Finance.” Journal of Financial Economics 70, 137-181.

Beck, T., Demirgüç-Kunt, A., and Levine, R. 2003. "Law and Finance: Why Does Legal Origin Matter?" Journal of Comparative Economics 31, 653-675.

Beck, T., Demirguc-Kunt, A. and Maksimovic, V. 2006. "Financing Patterns around the World: Are Small Firms Different?” World Bank mimeo.

Beck, T., Demirgüç-Kunt, A., and Maksimovic, V. 2004. "Financial and Legal Constraints to Firm Growth: Does Size Matter?” Journal of Finance 60, 137-177.

Beck, T., Demirguc-Kunt, A., and Maksimovic, V. 2004. "Bank Competition and Access to Finance: International Evidence." Journal of Money, Credit, and Banking 36(3), 627 48. 
Beck, T., Demirguc-Kunt, A., and Martinez Peria, M. 2005. "Reaching Out: Access To and Use of Banking Services across Countries." World Bank Policy Research Working Paper 3754.

Beck, T., and Fuchs, M. 2004. "Structural Issues in the Kenyan Financial System: Improving Competition and Access.” World Bank Policy Research Paper 3363.

Beck, T., and Levine, R. 2002. "Industry Growth and Capital Allocation: Does Having a Market- or Bank-Based System Matter?” Journal of Financial Economics 64, 147-180.

Beck, T., Levine, R., and Loayza, N. 2000. "Finance and the Sources of Growth, Journal of Financial Economics 58, 261-300.

Beck, T., Lundberg, M., and Majnoni, G. "Financial Intermediary Development and Growth Volatility: Do Intermediaries Dampen or Magnify Shocks?" Journal of International Money and Finance, forthcoming.

Becker, G. and Stigler, G. 1974. "Law Enforcement, Malfeasance, and the Compensation of Enforcers,” Journal of Legal Studies 3, 1-18.

Bekaert, G., Harvey, C.R., Lundblad, C. 2005. "Does Financial Liberalization Spur Growth?” Journal of Financial Economics. In press.

Bekaert, G., and Harvey, C.R. 2003. “Emerging Markets Finance.” Journal of Empirical Finance 10, 3-56.

Bekaert, G., Harvey, C.R., and Lundblad, C. 2001. "Emerging Equity Markets and Economic Development.” Journal of Development Economics 66, 465-504.

Bencivenga, V.R., and Smith, B.D. 1992. "Deficits, Inflation and the Banking System in Developing Countries: The Optimal Degree of Financial Repression.” Oxford Economic Papers 44, 767-790.

Berger, A., and Udell, G.F. 2006.“A More Complete Conceptual Framework for Financing of Small and Medium Enterprises.” Journal of Banking and Finance.

Berger, A., Demirguc-Kunt, A., Haubrich, J. and Levine, R. 2004. "Introduction: Bank Concentration and Competition: An Evolution in the Making." Journal of Money, Credit, and Banking 36(3), 433-53.

Bossone, B., Honohan, P., and Long, M. 2001. "Policy for Small Financial Systems.” Financial Sector Discussion Paper 6. World Bank.

Bertrand, M., Schoar, A.S., and Thesmar, D. 2004. "Banking Deregulation and Industry Structure: Evidence from the French Banking Reforms of 1985.” Discussion Paper No. 4488. Centre for Economic Policy Research. 
Boot, A.W.A., and Thakor, A. 1997. Financial system architecture, Review of Financial Studies 10, 693-733.

Boyd, J.H., Levine, R., and Smith, B.D. 2001. “The Impact of Inflation on Financial Sector Performance.” Journal of Monetary Economics 47, 221-248.

Boyd, J.H., and Prescott, E.C. 1986. “Financial Intermediary-Coalitions.” Journal of Economics Theory 38, 211-232.

Calvo, G. 1999. “Testimony on Full Dollarization.” Paper presented before a joint hearing of the subcommittees on Economic Policy and International Trade and Finance, US Congress, April.

Cecchetti, S. and Krause, S. 2004. “Deposit Insurance and External Finance,” NBER Working Paper No. 10908.

Christopoulos, D.K., and Tsionas, E.G. 2004. "Financial Development and Economic Growth: Evidence from Panel Unit Root and Cointegration Tests.” Journal of Development Economics 73, 55-74.

Claessens, S. 2005. "Access to Financial Services: A Review of the Issues and Public Policy Objectives.” World Bank Policy Research Working Paper 3589.

Claessens, S, and Laeven, L. 2004. "What Drives Bank Competition? Some International Evidence." Journal of Money, Credit, and Banking 36(3), 563-83.

Claessens, S., Demirguc-Kunt, A., and Huizinga, H. 2001. "How Does Foreign Entry Affect Domestic Banking Markets?" Journal of Banking and Finance 25(5): 891-911.

Clarke, G., Cull, R., Martinez Peria, M., and Sanchez, S. 2003. "Foreign Bank Entry: Experience, Implications for Developing Countries and Agenda for Further Research.” World Bank Research Observer 18, 25-59.

Clarke, G., Cull, R., and Martinez Peria, M. 2001. "Does Foreign Bank Penetration Reduce Access to Credit in Developing Countries: Evidence from Asking Borrowers.” World Bank Policy Research Working Paper 2716.

Clarke, G., Cull, R., and Shirley, M. 2005. "Bank Privatization in Developing Countries: A Summary of Lessons and Findings.” Journal of Banking and Finance 29, 1905-30.

Clarke, G., L. C. Xu and H. Zhou, 2003. "Finance and Income Inequality, Test of Alternative Theories,” World Bank Policy Research Working Paper, \#2984.

Cole, S. 2005. "Fixing Market Failures or Fixing Elections? Elections, Banks, and Agricultural Lending in India.” Harvard Business School mimeo.

Cull, R., Senbet, L., and Sorge, M. 2005. "Deposit Insurance and Financial Development." Journal of Money, Credit, and Banking 37, 43-82. 
De Haas, R., and Naaborg, I. 2005. “Does Foreign Bank Entry Reduce Small Firms' Access to Credit: Evidence from European Transition Economies.” Dutch National Bank Working Paper 50.

Demirguc-Kunt, A., and Detragiache, E. 2005. “Cross-Country Empirical Studies of Systemic Bank Distress: A Survey,” In Davis, P. (ed.), Financial Instability, Asset Prices, and Credit. National Institute Economic Review, forthcoming.

Demirguc-Kunt, A., and Detragiache, E. 2002. "Does Deposit Insurance Increase Banking System Stability? An Empirical Investigation." Journal of Monetary Economics 49:7, 1373-406.

Demirguc-Kunt A., and Detragiache, E. 1999. “Financial Liberalization and Financial Fragility.” In: Pleskovic, B., and Stiglitz, J. (eds.), Proceedings of the Annual World Bank Conference on Development Economics. The World Bank, pp. 332-34.

Demirgüç-Kunt, A. and Detragiache, E. 1998. "The Determinants of Banking Crises: Evidence from Developing and Developed Countries.” IMF Staff Papers 45, 81-109.

Demirgüç-Kunt, A. and Detragiache, E. and Tressel, T. 2006. "Banking on the Principles: Compliance with Basel Core Principles and Bank Soundness.” World Bank mimeo.

Demirguc-Kunt, A., and Huizinga, H. 2004. "Market Discipline and Deposit Insurance." Journal of Monetary Economics 51, 375-99.

Demirguc-Kunt, A., and Kane, E. 2002. "Deposit Insurance around the Globe: Where Does It Work?" Journal of Economic Perspectives 16(2), 175-96.

Demirguc-Kunt, A., Laeven, L., and Levine, R. 2004. "Regulations, Market Structure, Institutions, and the Cost of Financial Intermediation." Journal of Money, Credit, and Banking 36(3), 593-622.

Demirgüç-Kunt, A., and Levine, R. 2001. Financial Structure and Economic Growth: A Cross-Country Comparison of Banks, Markets, and Development. Cambridge, MA: MIT Press.

Demirgüç-Kunt, A., and Levine, R. 2001. “Financial Structure and Economic Growth: Perspectives and Lessons. In: Demirgüç-Kunt, A., and Levine, R. (eds.), Financial Structure and Economic Growth: A Cross-Country Comparison of Banks, Markets, and Development. Cambridge, MA:MIT Press, pp. 3-14.

Demirgüç-Kunt, A., and Levine, R. 2001. "Bank-Based and Market-Based Financial Systems: Cross-Country Comparisons.” In: Demirgüç-Kunt, A., and Levine, R. (eds.), Financial Structure and Economic Growth: A Cross-Country Comparison of Banks, Markets, and Development. Cambridge, MA:MIT Press, pp. 81-140. 
Demirgüç-Kunt A., and Levine, R. 1996. "Stock Market Development and Ffinancial Intermediaries: Stylized Facts.” World Bank Economic Review 10, 291-322.

Demirgüç-Kunt, A., and Maksimovic, V. 1998. "Law, Finance, and Firm Growth.” Journal of Finance 53, pp. 2107-2137.

Demirgüç-Kunt, A., and Maksimovic, V. 2002. "Funding Growth in Bank-Based and Market-Based Financial Systems: Evidence from Firm Level Data.” Journal of Financial Economic 65, 337-363.

De Nicolo, G., Honohan, P., and Ize, A. 2003. "Dollarization of the Banking System: Good or Bad:” IMF Working Paper 03/146.

Detragiache, E., Gupta, P., and Tressel, T. 2005. "Finance in Lower-Income Countries: An Empirical Exploration.” International Monetary Fund Working Paper, WP/05/167.

Dinc, S. 2005. Politicians and Banks. Political Influences on Government-Owned Banks in Emerging Countries, Journal of Financial Economics 77, 453-79.

Djankov, S., McLiesh, C., and Shleifer, A. 2005. "Private Credit in 129 Countries.” NBER Working Paper 11078.

Diamond, D.W. 1984. "Financial Intermediation and Delegated Monitoring." Review of Economic Studies 51, pp. 393-414.

Domac, I. and Martinez Peria, M. 2003. "Banking Crises and Exchange Rate Regimes: Is There a Link?’ Journal of International Economics 61(1), 41-72.

Easterly, W., and Levine, R. 2003. "Tropics, Germs, and Crops: How Endowments Influence Economic Development.” Journal of Monetary Economics 50, pp. 3-39.

Eichengreen, B. and Hausmann, R. 1999. "Exchange Rates and Financial Fragility.” National Bureau of Economic Research Working Paper No. 7418.

Eichengreen, B. and Rose, A. 1998. "Staying Afloat when the Wind Shifts: External Factors and Emerging-Market Banking Crises’, NBER Working Paper No. 6370, January.

Engerman, S.L., and Sokoloff, K.L. 1997. "Factor Endowments, Institutions, and Differential Paths of Growth among New World Economies: A View from Economic Historians of the United States.” In: Haber, S. (ed.), How Latin America Fell Behind. Stanford, CA:Stanford University Press, pp. 260-304.

Ferreira, M., and Matos, P. 2005. The Colors of Investors’ Money: Which Firms Attract Institutional Investors from around the World? 
Galor, O., and Zeira, J. 1993. "Income Distribution and Macroeconomics.” Review of Economic Studies 60, pp. 35-52.

Goldsmith, R.W. 1969. Financial Structure and Development. New Haven, CT:Yale University Press.

Greenwood, J., and Jovanovic, B. 1990. "Financial Development, Growth, and the Distribution of Income, Journal of Political Economy 98, pp. 1076-1107.

Guiso, L., Sapienza, P., Zingales, L. (2002). “Does local financial development matter?”. National Bureau of Economic Research Working Paper No. 8922.

Gurley, J.G., and Shaw, E.S. 1955. "Financial Aspects of Economic Development.” American Economic Review 45, pp. 515-538.

Haber, S.H. 2005. "Mexico's Experiment with Bank Privatization and Liberalization, 1991-2004". Journal of Banking and Finance. In press.

Haber, S.H. 2004. "Political Competition and Economic Growth: Lessons from the Political Economy of Bank Regulation in the United States and Mexico". Stanford University mimeo.

Haber, S.H., Maurer, N., and Razo, A. 2003. The Politics of Property Rights: Political Instability, Credible Commitments, and Economic Growth in Mexico. Cambridge University Press.

Hermes, N., and Lensink, R. 2003. "Foreign Direct Investment, Financial Development and Economic Growth.” Journal of Development Studies 38.

Honohan, P. 2004. "Financial Development, Growth, and Poverty: How Close Are the Links?" In Goodhart, C. (ed.), Financial Development and Economic Growth:

Explaining the Links. London: Palgrave.

Huybens, E., and Smith, R. 1999. "Inflation, Financial Markets, and Long-Run Real Activity.” Journal of Monetary Economics 43, 283-315.

Jappelli, T., and Pagano, M. 2002. "Information Sharing, Lending and Defaults: CrossCountry Evidence.” Journal of Banking and Finance 26:10, 2017-45.

Jayaratne, J., and Strahan, P.E. 1996. “The Finance-Growth Nexus: Evidence from Bank Branch Deregulation.” Quarterly Journal of Economics 111, 639-670.

Kaminsky, G. and Reinhart, C.M. 1999. "The Twin Crises: The Causes of Banking and Balance of Payments Problems.” American Economic Review 89, 473-500.

Kaminsky, G., and Schmukler, S. 2003. "Short-term Pain, Long-term Gain: The Effect of Financial Liberalization.” NBER Working Paper 9787. 
Kaminsky, G. and Schmukler, S. 2001. “On Financial Booms and Crashes: Regional Patterns, Time Patterns, and Financial Liberalization.” Policy Research Paper. World Bank.

Klapper, L. 2006. "The Role of Factoring for Financing Small and Medium Enterprises." Journal of Banking and Finance, forthcoming.

King, R.G., and Levine, R. 1993. "Finance and Growth: Schumpeter Might Be Right.” Quarterly Journal of Economics 108, 717-738.

Laeven, L., and Majnoni, G. 2005. "Does Judicial Efficiency Lower the Cost of Credit?” Journal of Banking and Finance 29, 1791-812.

Lamoreaux, N. 1994. Insider Lending: Banks, Personal Connections, and Economic Development in Industrial New England, New York:Cambridge University Press.

La Porta, R., Lopez-de-Silanes, F., and Shleifer, A. 2006. "What Works in Securities Laws?” Journal of Finance, forthcoming.

La Porta, R., Lopez-de-Silanes, F., Shleifer, A. 2002. "Government Ownership of Commercial Banks.” Journal of Finance 57, 265-301.

La Porta, R., Lopez-de-Silanes, F., Shleifer, A., and Vishny, R.W. 1998. "Law and Finance.” Journal of Political Economy 106, 1113-1155.

La Porta, R., Lopez-de-Silanes, F., Shleifer, A., and Vishny, R.W. 1997. “Legal Determinants of External Finance.” Journal of Finance 52, 1131-1150.

Levine, R. 2005. "Finance and Growth: Theory and Evidence.” In Aghion, P. and Durlaff, S. (eds.), Handbook of Economic Growth. Elsevier Science. The Netherlands.

Levine, R. 2002. “Bank-Based or Market-Based Financial Systems: Which is Better?” Journal of Financial Intermediation 11, 398-428.

Levine, R. 1997. "Financial Development and Economic Growth: Views and Agenda, Journal of Economic Literature 35, 688-726.

Levine, R., Loayza, N., and Beck, T. 2000. "Financial Intermediation and Growth: Causality and Causes.” Journal of Monetary Economics 46, 31-77.

Levine, R., and Zervos, S. 1998. "Stock Markets, Banks, and Economic Growth.” American Economic Review 88, 537-558.

Love, I. 2003. "Financial Development and Financing Constraint: International Evidence from the Structural Investment Model.” Review of Financial Studies 16, 765-791. 
Love, I., and Mylenko, N. 2004. "Credit Reporting and Financing Constraints." World Bank Policy Research Working Paper 3142.

Lucas, R.E. 1988. “On the Mechanics of Economic Development.” Journal of Monetary Economics 22, 3-42.

Merton, R.C., Bodie, Z. 2004. "The Design of Financial Systems: Towards a Synthesis of Function and Structure.” National Bureau of Economic Research Working Paper Number 10620.

Miller, M. 2003. Credit Reporting Systems and the International Economy. MIT Press, Cambridge, Mass.

Morck, R., Wolfenzon, D., Yeung, B. 2005. “Corporate Governance, Economic Entrenchment and Growth”. Journal of Economic Literature. In press.

Mundell, R. 1961. “A Theory of Optimum Currency Areas.” American Economic Review 51, 717-25.

Pagano, M., and Volpin, P. 2001. "The Political Economy of Finance.” Oxford Review of Economic Policy 17, 502-519.

Raddatz, C. 2006. "Liquidity Needs and Vulnerability to Financial Underdevelopment.” Journal of Financial Economics, forthcoming.

Rajan, R. (March) 2006. "Separate and Unequal.” Finance and Development, International Monetary Fund, Washington D.C., 56-57.

Rajan, R.G., and Zingales, L. 2003. Saving Capitalism from the Capitalists. New York:Random House.

Rajan, R.G., and Zingales, L. 1998. “Financial Dependence and Growth.” American Economic Review 88, 559-586.

Robinson, J. 1952. The Rate of Interest and Other Essays. London:MacMillan (Chapter "The generalization of the general theory”).

Roubini, N., and Sala-i-Martin, X. 1992. "Financial Repression and Economic Growth." Journal of Development Economics 39, 5-30.

Roubini. N., and Sala-i-Martin, X. 1995. “A Growth Model of Inflation, Tax Evasion, and Financial Repression.” Journal of Monetary Economics 35, 275-301.

Rousseau, P.L., Sylla, R. 1999. “Emerging Financial Markets and Early U.S. Growth.” National Bureau of Economic Research Working Paper No. 7448. 
Stigler, G. 1971. "The Theory of Economic Regulation.” Bell Journal of Economics and Management Science 2, 3-21.

Stulz, R.M., and Williamson, R. 2003. "Culture, Openness, and Finance.” Journal of Financial Economics 70, 313-349.

World Bank. 2001. Finance for Growth: Policy Choices in a Volatile World. Policy Research Report. Washington, DC.

Wurgler, J. 2000. "Financial Markets and the Allocation of Capital.” Journal of Financial Economics 58, pp. 187-214.

Yagci, F. 2006. “Choice of Exchange Rate Regimes for Developing Countries.” In: Bourguignon F. and Monga, C. (eds.), Macroeconomic Issues in Low-Income Countries. Washington D.C., forthcoming. 
Table 1. Financial Indicators : Summary Statistics by Income Group

\author{
Full Sample \\ Private Credit / GDP \\ Stock Market Capitalization \\ Net Interest Margin \\ M2 (mil. 2000 USD) \\ Number of Loans per 1000 People \\ Freedom Score - Banking \& Finance
}

\section{High Income Countries}

Private Credit / GDP

Stock Market Capitalization

Net Interest Margin

M2 (mil. 2000 USD)

Number of Loans per 1000 People

Freedom Score - Banking \& Finance

\section{Upper Middle Income Countries}

Private Credit / GDP

Stock Market Capitalization

Net Interest Margin

M2 (mil. 2000 USD)

Number of Loans per 1000 People

Freedom Score - Banking \& Finance

\section{Lower Middle Income Countries}

Private Credit / GDP

Stock Market Capitalization

Net Interest Margin

M2 (mil. 2000 USD)

Number of Loans per 1000 People

Freedom Score - Banking \& Finance

\section{Low-Income Countries}

Private Credit / GDP

Stock Market Capitalization

Net Interest Margin

M2 (mil. 2000 USD)

Number of Loans per 1000 People

Freedom Score - Banking \& Finance

\author{
No. of Obs.
}

$\begin{array}{rr}156 & 0.447 \\ 107 & 0.465 \\ 156 & 0.053 \\ 159 & 123,757 \\ 44 & 200.02 \\ 163 & 3.0\end{array}$

No. of Obs.

\section{Mean}

Std. Dev.

0.416
0.550
0.034
735,395
222.50
1.0

Min

$\begin{array}{ll}0.008 & 2.067 \\ 0.004 & 3.798 \\ 0.009 & 0.240\end{array}$

20

$6,604,461$

4.44

771.80

$1.0 \quad 5.0$

$\begin{array}{rr}0.379 & 0.294 \\ 0.688 & 0.098 \\ 0.009 & 0.009 \\ 1,820,871 & 3,423 \\ 247.99 & 48.75 \\ 0.9 & 1.0\end{array}$

2.067

3.798

0.051

$6,604,461$

753.98

3.5
No. of Obs.

$\begin{array}{lr}32 & 0.442 \\ 25 & 0.374 \\ 28 & 0.053 \\ 35 & 25,293 \\ 11 & 251.81 \\ 29 & 2.6\end{array}$

No. of Obs.

$\begin{array}{lr}40 & 0.307 \\ 30 & 0.213 \\ 41 & 0.062 \\ 48 & 58,545 \\ 18 & 74.41 \\ 46 & 3.2\end{array}$

No. of Obs.

$\begin{array}{rc}47 & 0.137 \\ 16 & 0.132 \\ 42 & 0.075 \\ 53 & 7,910 \\ 5 & 37.33 \\ 51 & 3.6\end{array}$

Std. Dev.

0.316
0.395
0.029
37,628
211.23
0.9

0.10

0.019

0.018

112

53.85

1.0

Mean

Std. Dev.

0.207
0.214
0.028
294,801
54.00
0.9

0.029

0.005

0.011

72

4.44

1.5

Max

1.306
1.470
0.150
162,953
771.80
5.0

Max

$$
\begin{array}{r}
1.018 \\
0.844 \\
0.127 \\
2,045,992 \\
249.60 \\
5.0
\end{array}
$$

Std. Dev. Min Max

$\begin{array}{crc}0.091 & 0.008 & 0.399 \\ 0.136 & 0.004 & 0.529 \\ 0.039 & 0.025 & 0.240 \\ 40,830 & 20 & 296,826 \\ 39.73 & 4.50 & 98.11 \\ 0.8 & 2.5 & 5.0\end{array}$


Figure 1. Private Credit / GDP

(a)

Distribution by Income Group (mean)

1. High Income

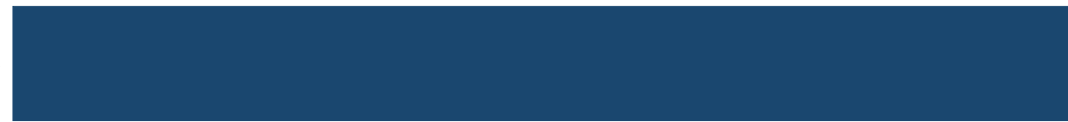

2. Upper Middle Income

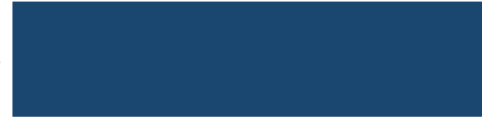

3. Lower Middle Income

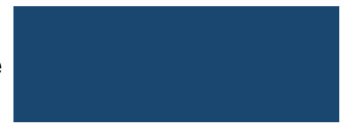

4. Low Income

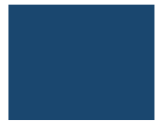

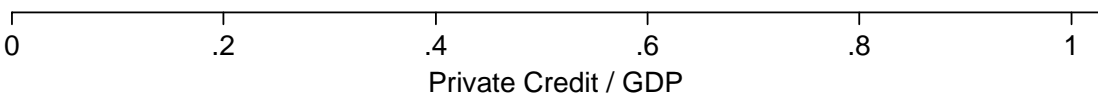

Sample size: 156 countries

Time period: $2000-2004$ Avg.

Source: Beck et. al. 2006. Financial Structure Database (The World Bank)

(b)

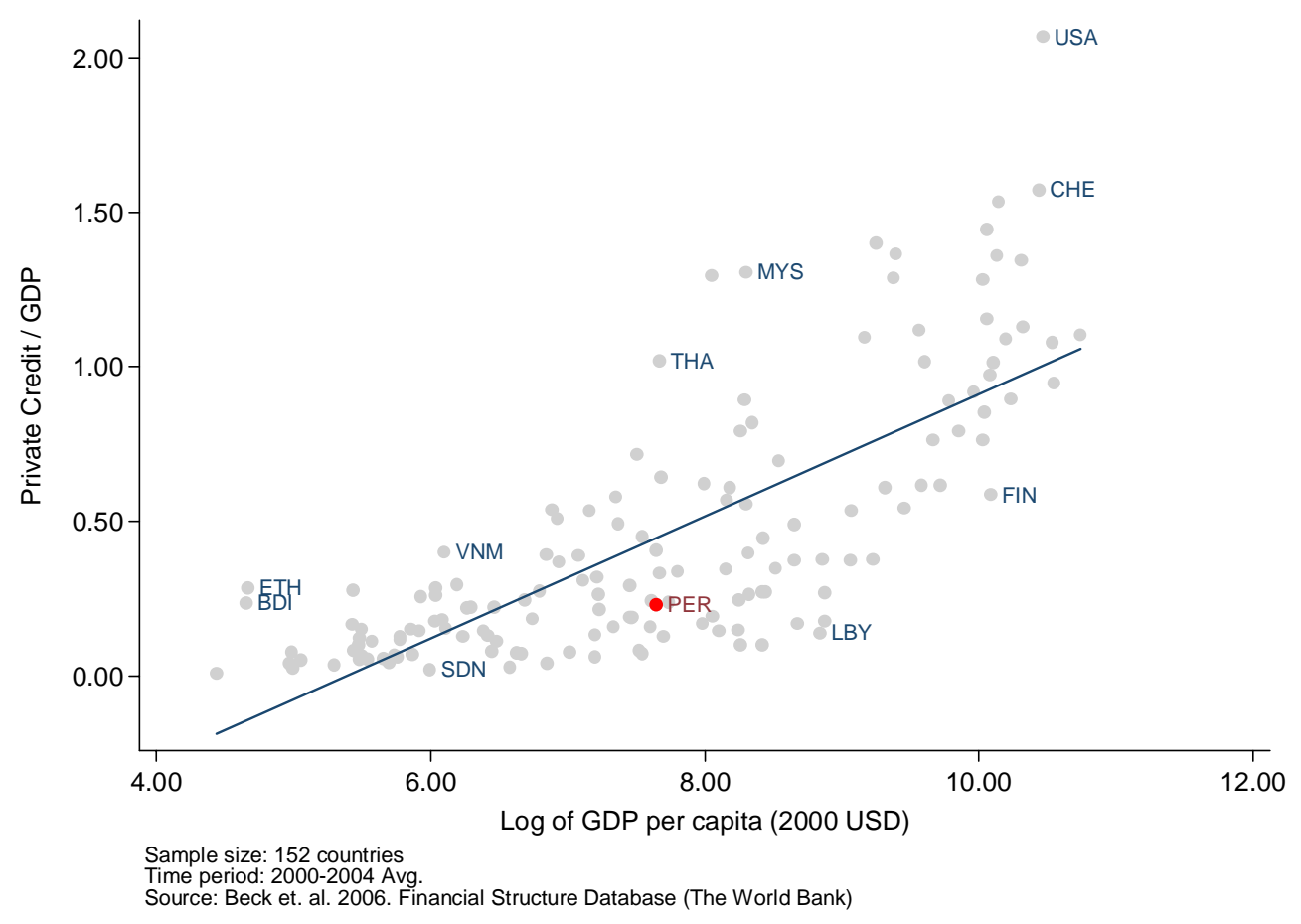




\section{Figure 2. Stock Market Capitalization / GDP}

(a)

Distribution by Income Group (mean)

1. High Income

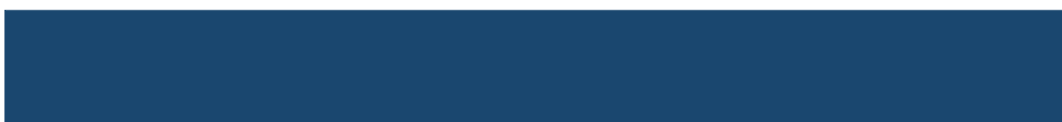

2. Upper Middle Income

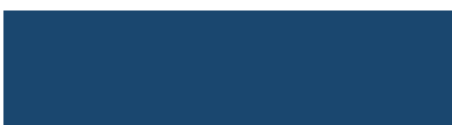

3. Lower Middle Income

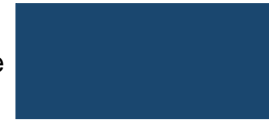

4. Low Income

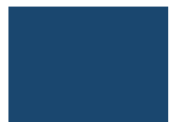

0

.2

.4

6

.8

Sample size: 107 countries

Time period: $2000-2004$ Avg.

Source: Beck et. al. 2006. Financial Structure Database (The World Bank)

(b)

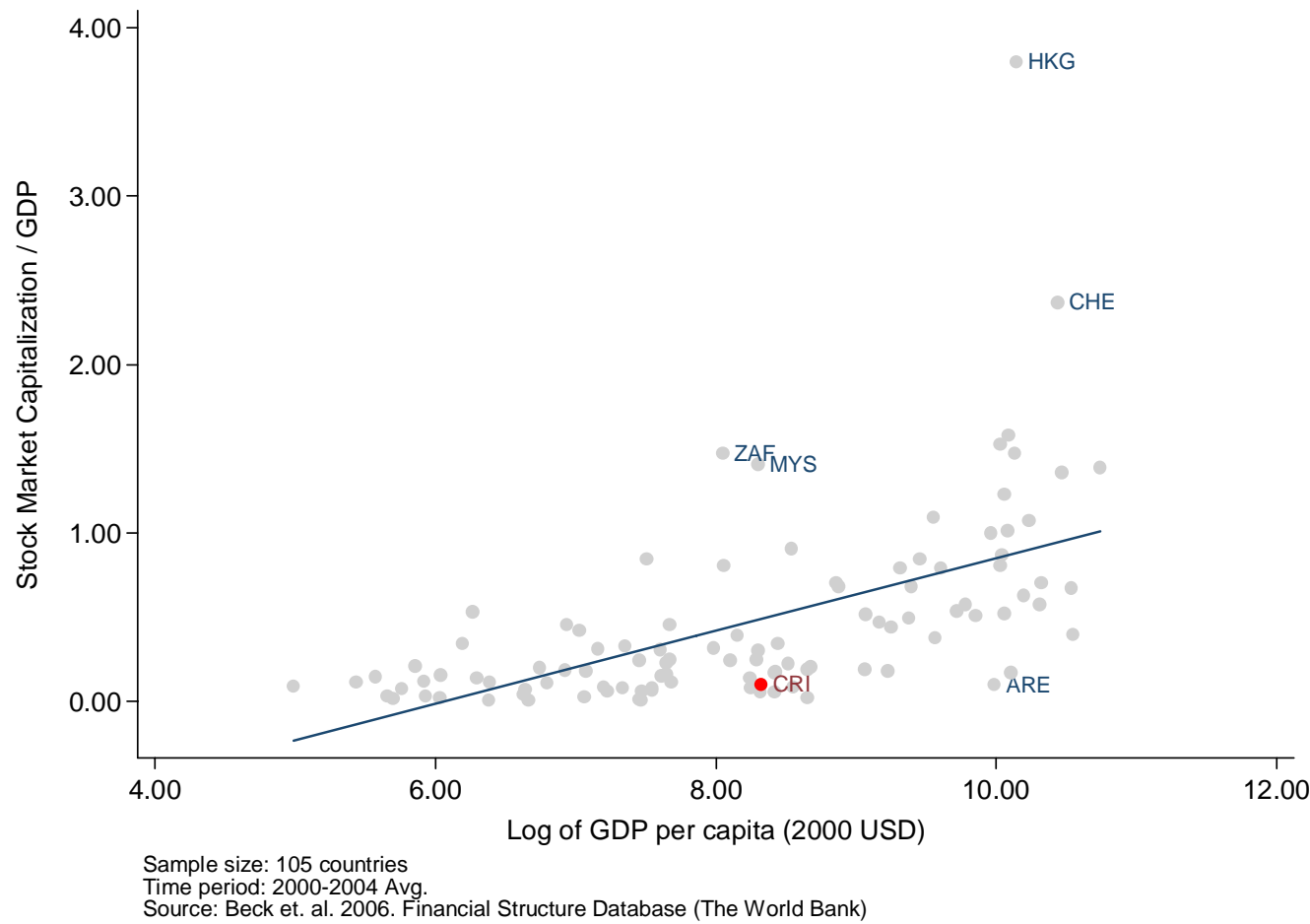


Figure 3. Net Interest Margin

(a)

Distribution by Income Group (mean)

1. High Income

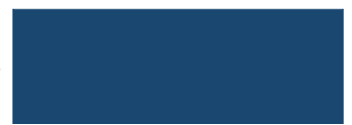

2. Upper Middle Income

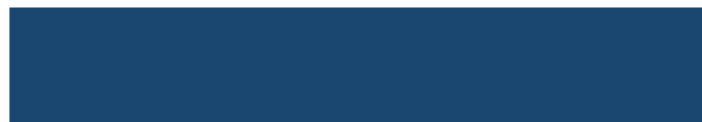

3. Lower Middle Income

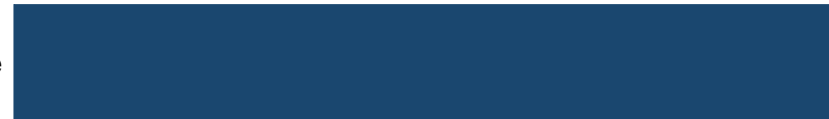

4. Low Income

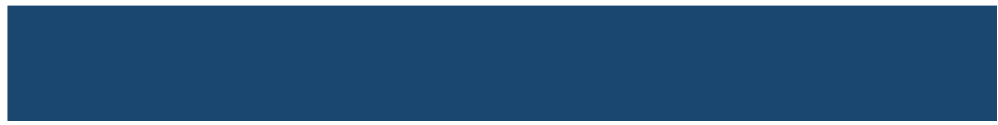

0

.02

.04

.06

.08

Net Interest Margin

Sample size: 156 countries

Time period: $2000-2004$ Avg.

Source: Beck et. al. 2006. Financial Structure Database (The World Bank)

(b)

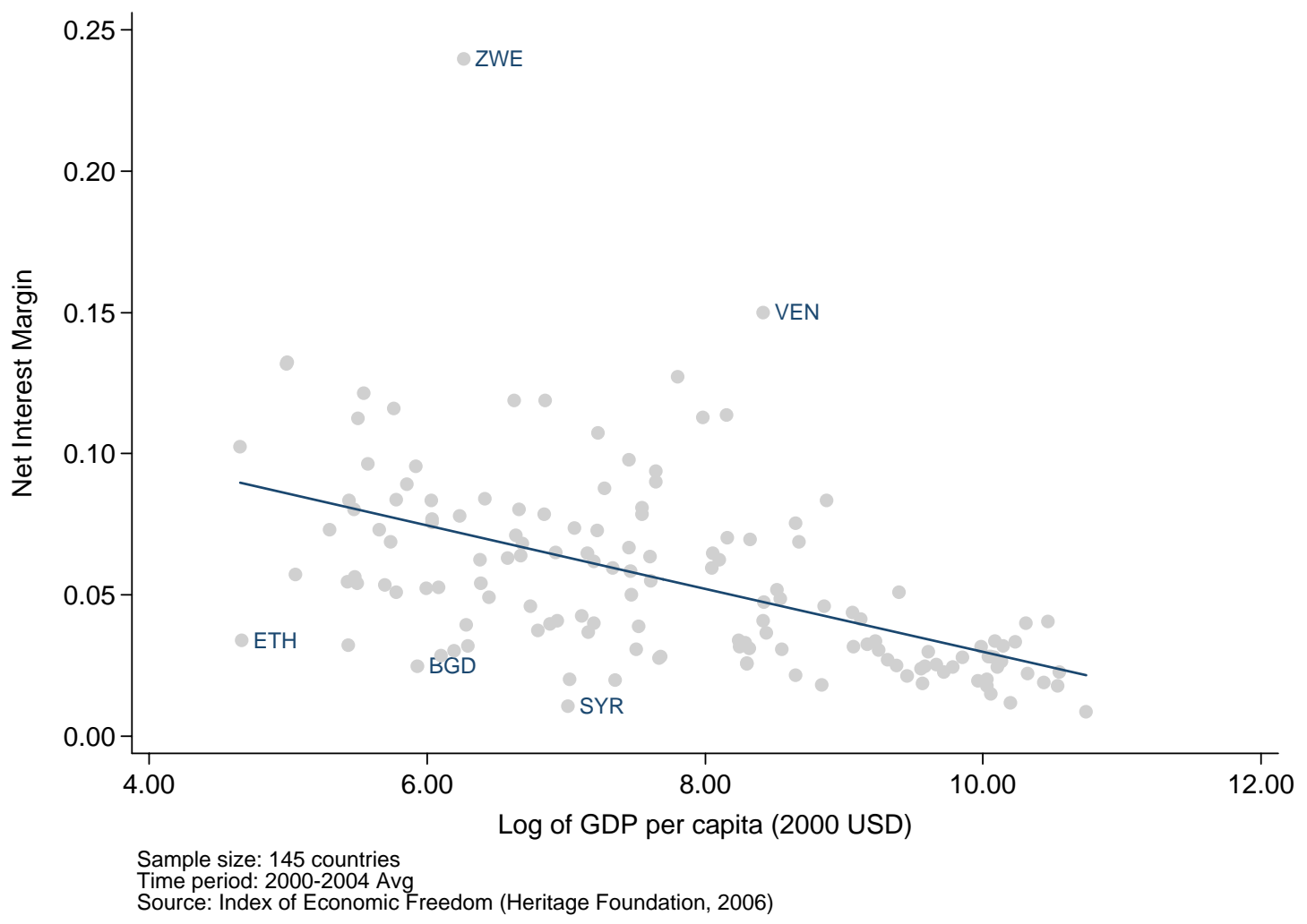


Figure 4. Bank Loans per 1000 People

(a)

Distribution by Income Group (mean)

1. High Income

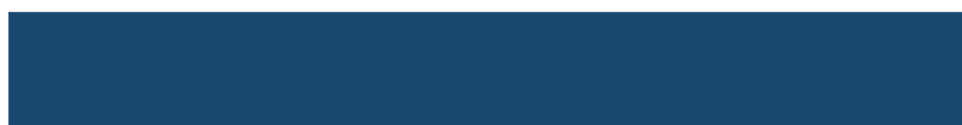

2. Upper Middle Income

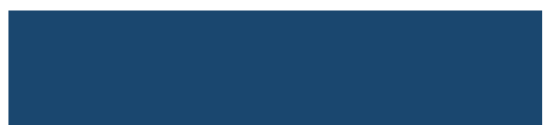

3. Lower Middle Income

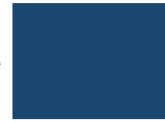

4. Low Income

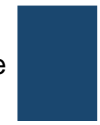

\begin{tabular}{|c|c|c|c|c|c|}
\hline 0 & 100 & 200 & 300 & 400 & 500 \\
\hline \multicolumn{6}{|c|}{ Number of Loans per 1000 People } \\
\hline
\end{tabular}

Sample size: 44 countries

Time period: $2000-2004$ Avg

Source: Beck, Demirguc-Kunt and Martinez Peria. 2005. Reaching Out Dataset

(b)

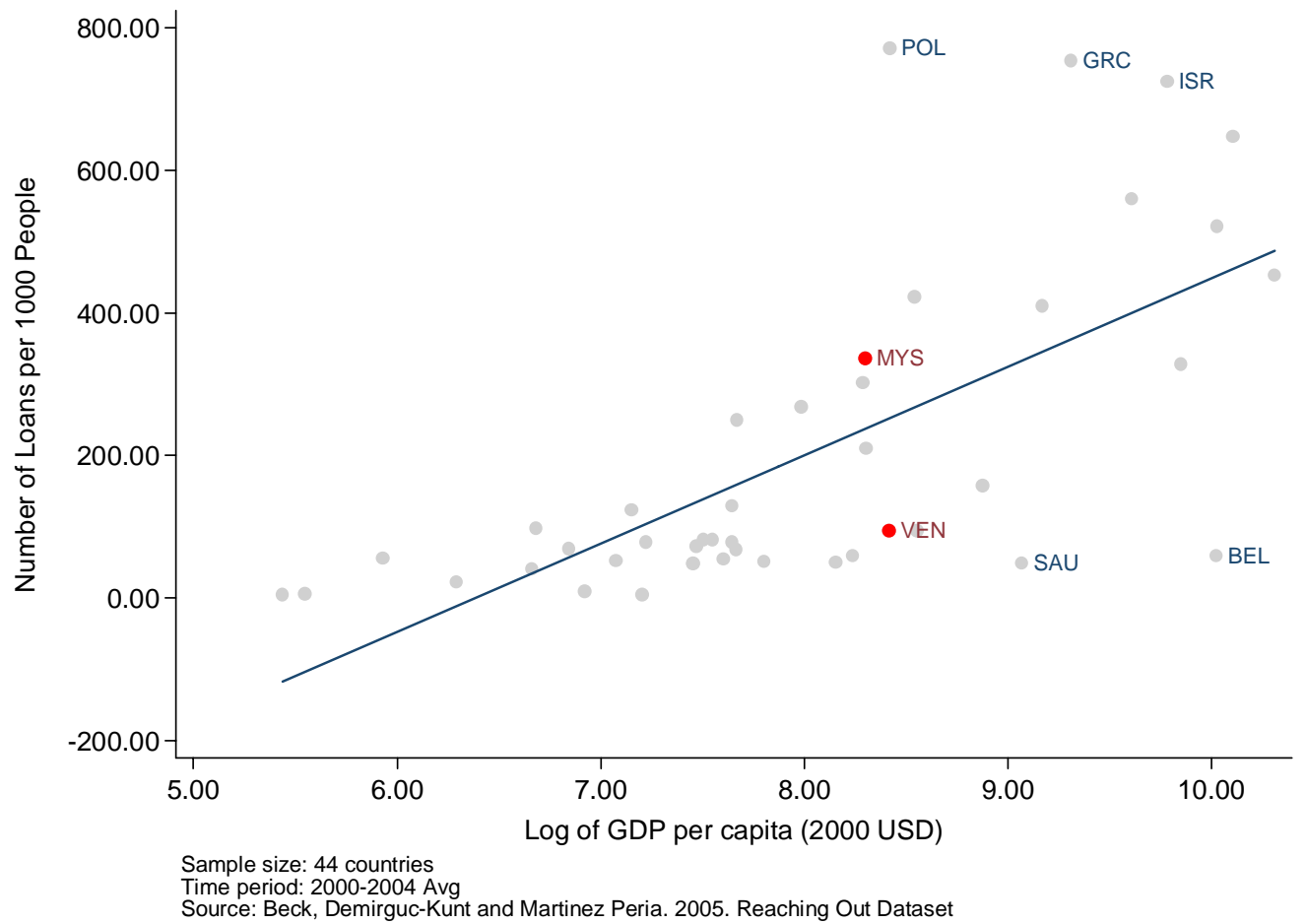




\section{Figure 5. Money Supply}

(a)

Distribution by Income Group (mean)

1. High Income

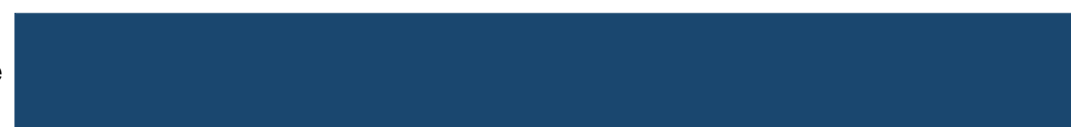

2. Upper Middle Income

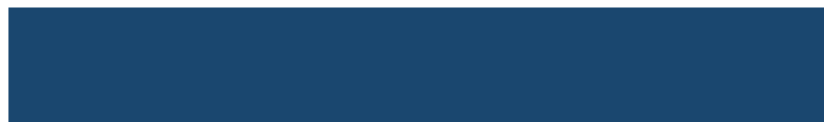

3. Lower Middle Income

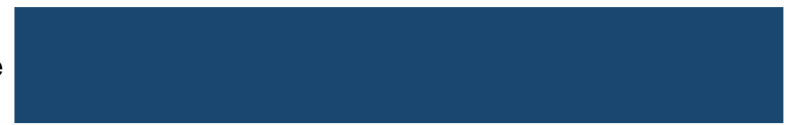

4. Low Income

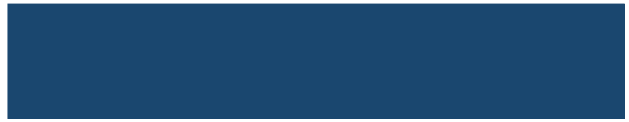

0

Log of M2 (mil. 2000 USD)

Sample size: 159 countries

Time period: $2000-2004$ Avg.

Source: Beck et. al. 2006. Financial Structure Database (The World Bank)

(b)

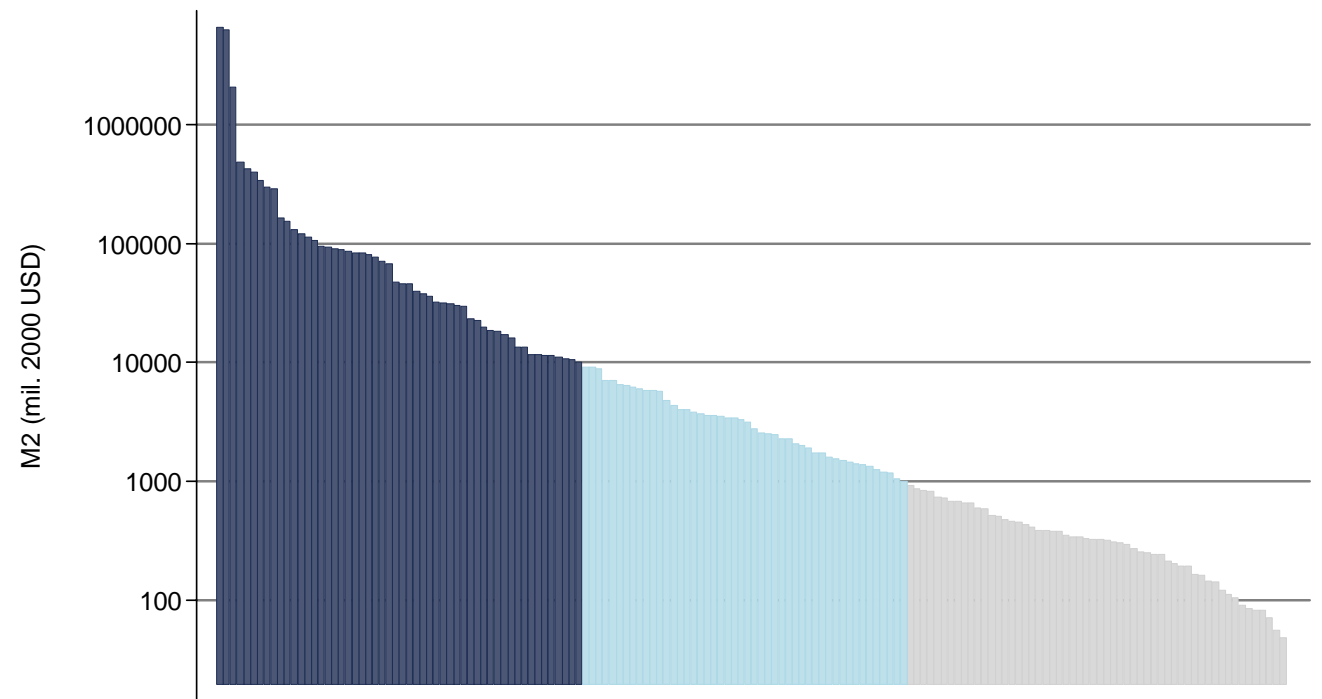

$<1$ bil. USD

1 - 10 bil. USD

$>10$ bil. USD

Sample size: 159 countries

Time period: $2000-2004 \mathrm{Avg}$

Note: All values are in 2000 USD

Source: Beck et. al. 2006. Financial Structure Database (The World Bank) 
Figure 6. Banking and Finance Freedom Index

(a)

Distribution by Income Group (mean)

1. High Income

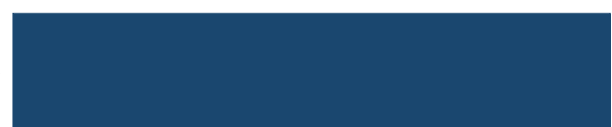

2. Upper Middle Income

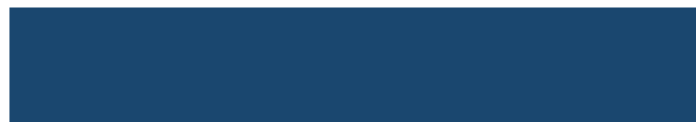

3. Lower Middle Income

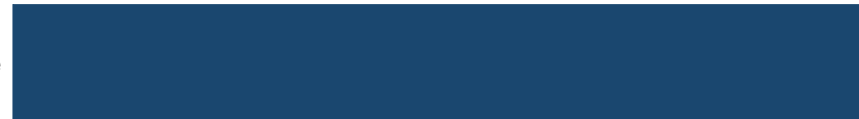

4. Low Income

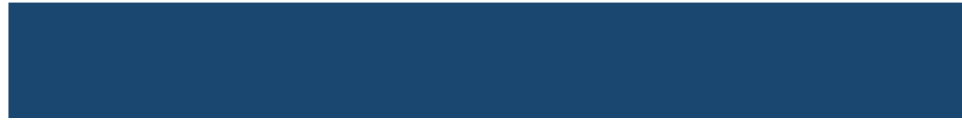

0

1

2

3

Freedom Score - Banking \& Finance

Sample size: 163 countries

Time period: $2000-2004$ Avg

Source: Index of Economic Freedom (Heritage Foundation, 2006)

(b)

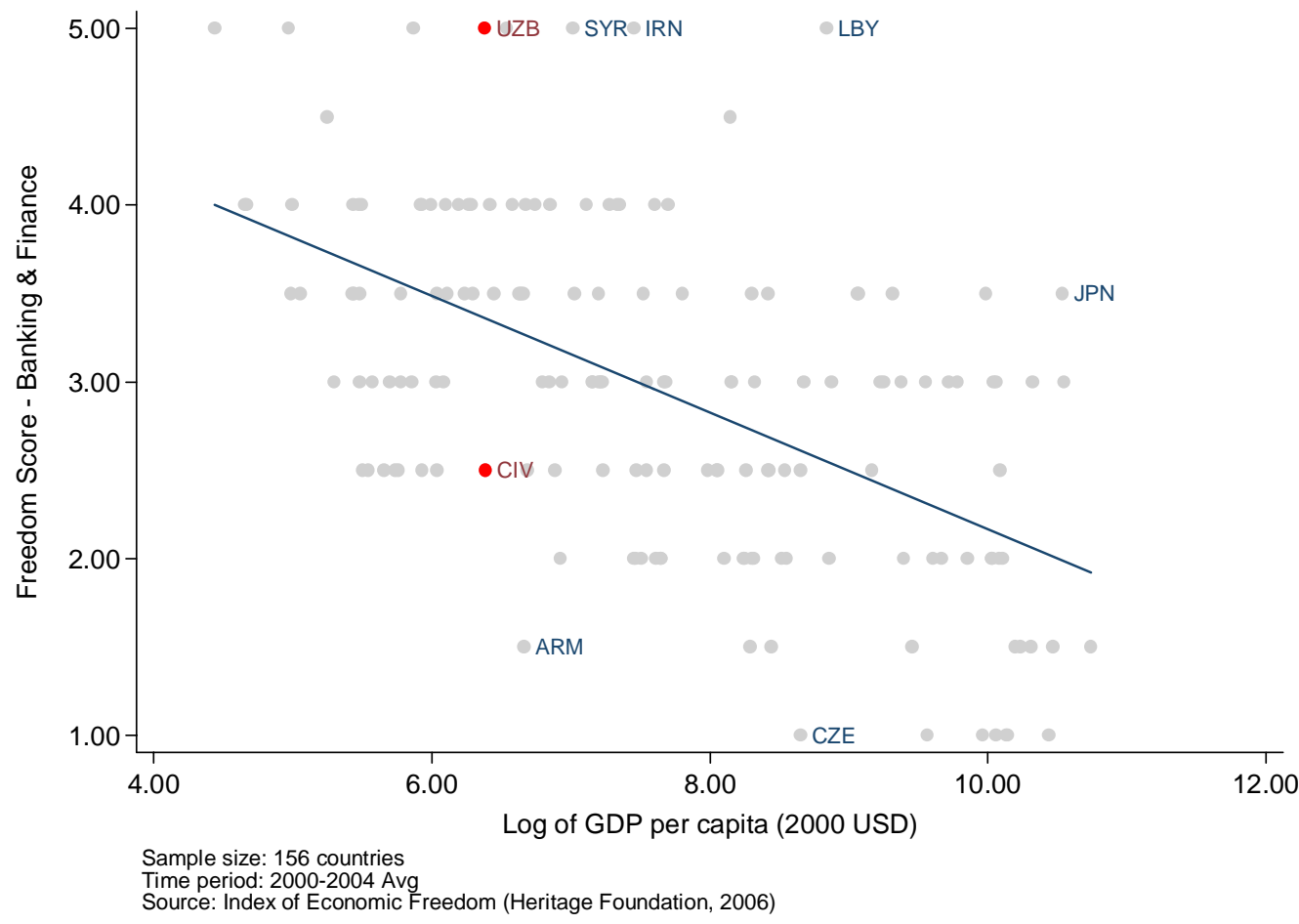

